\title{
Evaluation and
} Testing of the Cells Unit Crossflow Filter on INEEL Dissolved Calcine Slurries

N. R. Mann

T. A. Todd

LOCKHEED MARTIN 



\section{DISCLAIMER}

Portions of this document may be illegible in electronic image products. Images are produced from the best available original document. 


\title{
Evaluation and Testing of the Cells Unit Crossflow Filter on INEEL Dissolved Calcine Slurries
}

\author{
N. R. Mann \\ T. A. Todd
}

Published August 1998

Idaho National Engineering and Environmental Laboratory High-Level Waste Program

Lockheed Martin Idaho Technologies Company

Idaho Falls, Idaho 83415

Prepared for the

U.S. Department of Energy

Assistant Secretary for Environmental Management

Under DOE Idaho Operations Office

Contract DE-AC07-94ID13223 


\section{EXECUTIVE SUMMARY}

Development of waste treatment processes for the remediation of radioactive wastes is currently under way at the Idaho Nuclear Technology and Engineering Center (INTEC), located at the Idaho National Engineering and Environmental Laboratory (INEEL). INTEC, formerly known as the Idaho Chemical Processing Plant, previously reprocessed nuclear fuel to retrieve fissionable uranium.

Liquid waste raffinates resulting from reprocessing were solidified into a granular calcine material. Approximately $4,000 \mathrm{~m}^{3}$ of calcine are presently being stored in concrete encased stainless steel bins at the INTEC. Greater than 99 weight percent of the calcine is non-radioactive inert materials. By separating radioactive and nonradioactive constituents into high and low activity fractions, a significant high-activity volume reduction can be achieved. Prior to separation, calcine dissolution must be performed. However, dissolution studies have shown a small percentage of solids present after dissolution. Undissolved solids (UDS) in solution must be removed prior to downstream processes such as solvent extraction and ion exchange. Furthermore, residual UDS in solutions have the potential to carry excess radioactivity into low activity waste fractions, if not removed

Filtration experiments were conducted at the INEEL using the Cells Unit Filter (CUF) on actual dissolved H-4 calcine and dissolved Run 1027 non-radioactive pilot plant calcine. The purpose of this testing was to evaluate the removal and operational efficiency of crossflow filtration on slurries of various solids loadings. The solids loadings tested were, $0.19,2.44(\mathrm{H}-4)$ and 7.94 (1027) weight percent, respectively.

A matrix of test patterns was used to determine the effects of transmembrane pressure and axial velocity on filtrate flux. Filtrate flux rates for each solids loading displayed a high dependence on transmembrane pressure, indicating that pressure filtration resistance limits filtrate flux. Filtrate flux rates for all solids loading displayed a negative dependency on axial velocity. This would suggest axial velocities tested were efficient at removing filter cake.

Prior to testing of actual waste slurries, baseline water runs were performed. Filtrate flowrates observed during baseline water runs exhibited substantial decreases despite numerous backpulses and rinses, suggesting particles that were deeply

embedded within the filter membrane as the result of shear-induced deagglomeration. 
Backpulse efficiencies were determined by calculating the ratio of average steady state filtrate flow immediately preceding a backpulse by the average filtrate flow for 20 minutes after backpulse. This ratio is an indication of the effectiveness of the backpulse. Ratios may also indicate what filter mechanism is present for a specific operating condition. These data indicate a significant limitation to back-transport for the slurries with lower solids loadings, whereas slurries with high solids loadings showed little or no limitation to back-transport. Data suggests backpulsing efficiency increases with increased solids loading indicating a transition from Regime I (pressure filtration resistance) to Regime II (mass transport resistance) with increased solids loading. It would appear that flowrates tested are efficient at removing filter cake from the filter media, assisting in backpulse efficiency. Experimental results indicate that crossflow filtration may be an effective means of removing undissolved solids from dissolved calcine slurries. 


\section{ACKNOWLEDGEMENTS}

This work was supported by the U.S. Department of Energy, Office of Science and Technology's Tanks Focus Area. The authors would like to acknowledge Phil McGinnis, Daniel McCabe, Charles Nash and Julie Tripp for their support of this test.

The authors would also like to express their appreciation to Earlen Wade and Carl Lundholm for their efforts with laboratory testing. Scott Herbst is also acknowledged for his support, useful discussions and preparation of dissolved calcine feeds. 


\section{CONTENTS}

EXECUTIVE SUMMARY $\ldots \ldots \ldots \ldots \ldots \ldots \ldots \ldots \ldots \ldots \ldots \ldots \ldots \ldots \ldots \ldots \ldots$

ACKNOWLEDGEMENTS $\ldots \ldots \ldots \ldots \ldots \ldots \ldots \ldots \ldots \ldots \ldots \ldots \ldots \ldots \ldots$

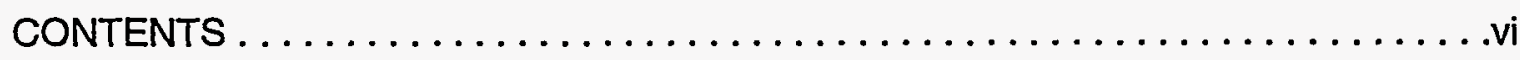

LIST OF TABLES $\ldots \ldots \ldots \ldots \ldots \ldots \ldots \ldots \ldots \ldots \ldots \ldots \ldots \ldots \ldots \ldots \ldots \ldots \ldots \ldots$

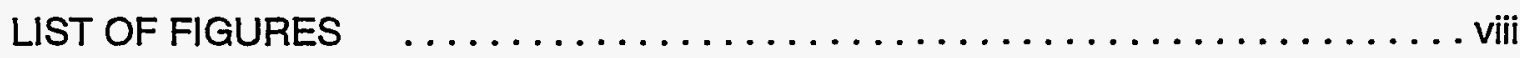

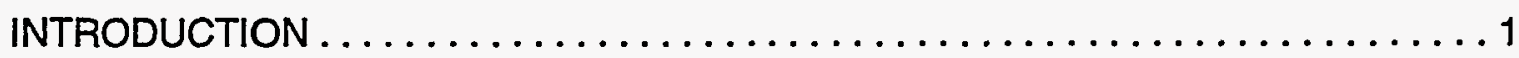

Crossflow Filtration Technology $\ldots \ldots \ldots \ldots \ldots \ldots \ldots \ldots \ldots \ldots \ldots \ldots \ldots \ldots \ldots$

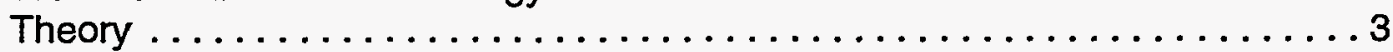

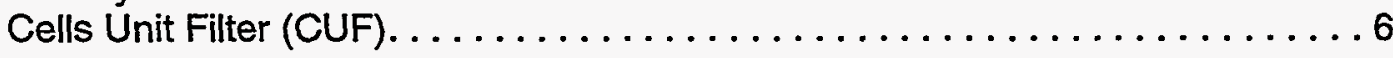

EXPERIMENTAL PROCEDURE. $\ldots \ldots \ldots \ldots \ldots \ldots \ldots \ldots \ldots \ldots$

Test Conditions ........................................

Baseline Water Run Conditions . . . . . . . . . . . . . . . . . . 10

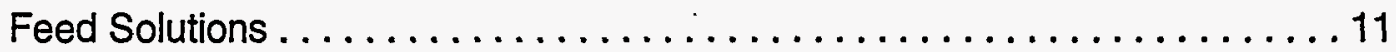

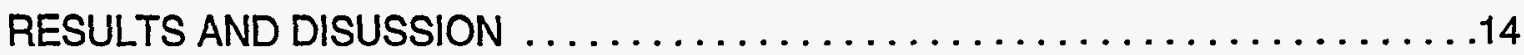

Baseline Water Run Results ...........................

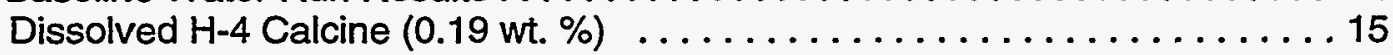

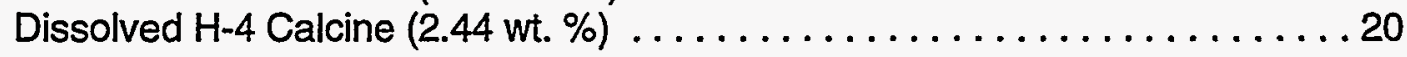

Non-Radioactive Dissolved Run 1027 Pilot Plant Calcine

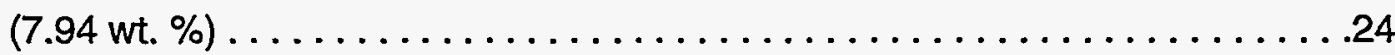

Solids Loadings Comparison . . . . . . . . . . . . . . . . . . 28

Filter Efficiency . .................................... 30

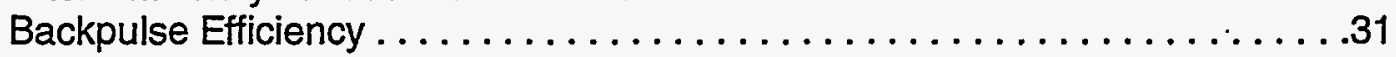

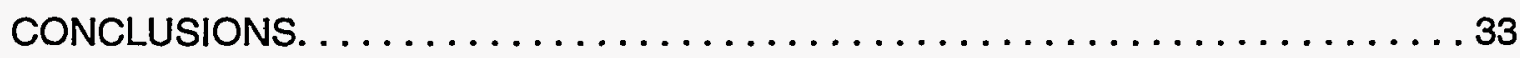

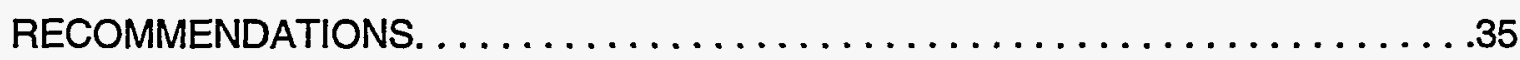

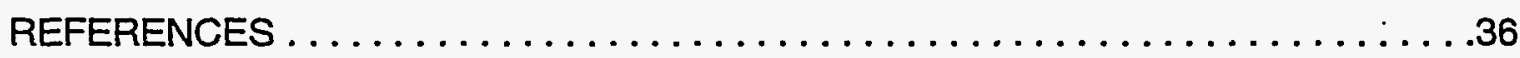

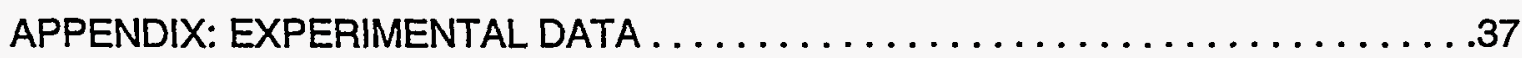




\section{LIST OF TABLES}

Table 1. Conditions and run order used in testing of the CUF apparatus $\ldots \ldots \ldots \ldots 9$

Table 2. Nine experimental baseline water run test conditions ..............11

Table 3. Composition of dissolved $\mathrm{H}-4$ calcine solution . . . . . . . . . . . 12

Table 4. Composition of non-radioactive pilot-plant dissolved Run 1027 calcine . . . . 13

Table 5. Filter efficiencies for 2.44 and 7.94 weight percent solids loading . . . . . .30 


\section{LIST OF FIGURES}

Figure 1. Comparison of traditional dead-end filtration with crossflow filtration . . . . 2

Figure 2. Schematic representation of crossflow filtration $\ldots \ldots \ldots \ldots \ldots \ldots \ldots$

Figure 3. Schematic of the CUF apparatus . . . . . . . . . . . . . . . . 7

Figure 4. CUF installed in the Remote Analytical Laboratory (photo) . . . . . . . . .8

Figure 5. Statistically designed experimental test conditions . . . . . . . . . . 10

Figure 6. Filtrate flowrate $(\mathrm{mL} / \mathrm{sec})$ for each of the 10 conditions tested . . . . . . 15

Figure 7. Filtrate flux as a function of time since backpulse for conditions 1 through 13 at 0.19 weight percent solids loading ............ 16

Figure 8. Filtrate flux as a function of time since backpulse for conditions

1,6 and 11 , at 0.19 weight percent solids loading . . . . . . . . . .17

Figure 9. Filtrate flux as a function of transmembrane pressure at $3.7 \mathrm{gpm}$ (Averages) for 0.19 weight percent solids loading . . . . . . . . . . 19

Figure 10. Filtrate flux as a function of axial velocity at $20 \mathrm{psig}$ (averages) for 0.19 weight percent solids loading . . . . . . . . . . . . . . 19

Figure 11. Filtrate flux as a function of time since backpulse for conditions 1 through 13 at 2.44 weight percent solids loading . . . . . . . . . 20

Figure 12. Filtrate flux as a function of time since backpulse for conditions 1,6 and 11 , at 2.44 weight percent solids loading $\ldots \ldots \ldots \ldots \ldots$

Figure 13. Filtrate flux as a function of transmembrane pressure at $3.7 \mathrm{gpm}$ (Averages) for 2.44 weight percent solids loading ............23

Figure 14. Filtrate flux as a function of axial velocity at 20 psig (averages) for 2.44 weight percent solids loading . . . . . . . . . . . . . 23

Figure 15. Filtrate flux as a function of time since backpulse for conditions 1 through 13 at 7.94 weight percent solids loading . . . . . . . . . . 24

Figure 16. Filtrate flux as a function of time since backpulse for conditions 1,6 and 11 at 7.94 weight percent solids loading $\ldots \ldots \ldots \ldots \ldots \ldots . \ldots 25$

Figure 17. Filtrate flux as a function of transmembrane pressure at $3.7 \mathrm{gpm}$ (Averages) for 7.94 weight percent solids loading . . . . . . . . 27

Figure 18. Filtrate flux as a function of axial velocity at 20 psig (averages) for 7.94 weight percent solids loading . . . . . . . . . . . . . 27

Figure 19. Filtrate flux as a function of transmembrane pressure for 0.19 , 2.44 and 7.94 weight percent solids loading . . . . . . . . . . . 28

Figure 20. Filtrate flux as a function of axial velocity for 0.19 , 2.44 and 7.94 weight percent solids loading . . . . . . . . . . . . 29

Figure 21. Backpulse ratios for $0.19,2.44$ and 7.94 weight percent solids loadings . . .32 


\section{Evaluation and Testing of the Cells Unit Crossflow Filter on INEEL Dissolved Calcine Slurries}

\section{INTRODUCTION}

Development of waste treatment processes for the remediation of radioactive wastes is currently under way at the Idaho Nuclear Technology and Engineering Center (INTEC), located at the Idaho National Engineering and Environmental Laboratory (INEEL). INTEC, formerly known as the Idaho Chemical Processing Plant, previously reprocessed nuclear fuel to retrieve fissionable uranium.

Liquid waste raffinates resulting from reprocessing were solidified into a granular calcine material. Approximately $4,000 \mathrm{~m}^{3}$ of calcine are presently being stored in concrete encased stainless steel bins at the INTEC. Two primary calcine types are present at the INTEC. They are classified as zirconium and aluminum, based on the type of fuel reprocessing raffinates calcined. Greater than 99 weight percent of the calcine is comprized of inert materials. By separating radioactive and non-radioactive constituents into high and low activity fractions, a significant high-activity volume reduction can be achieved.

Prior to separation, calcine dissolution must be performed. However, dissolution studies have shown a small percentage of solids present after dissolution. Undissolved solids (UDS) in solution must be removed prior to downstream processes such as solvent extraction and ion exchange. Furthermore, UDS have the potential to carry excess radioactivity into low activity waste, if not removed.

The Cells Unit Filter (CUF) was designed and fabricated at the Savannah River Site and then transported to the INEEL for testing. In FY-97, the CUF unit was installed in the Remote Analytical Laboratory (RAL) hot cell, where initial testing was performed using actual tank waste and non-radioactive dissolved calcine (1). 


\section{CROSSFLOW FILTRATION TECHNOLOGY}

Several solid/liquid separation technologies have been tested at various DOE sites. One potential technology under consideration is crossflow filtration. Crossflow filtration operates differently than traditional filtration methods. Crossflow filtration operates by recirculating the feed flow parallel to the filter membrane. The velocity of the suspension in recirculation sweeps away particles concentrated on the filter membrane, thereby limiting the thickness of filter cake. Permeate flows perpendicular to the feed stream rather than parallel to the feed stream. Traditional filtration methods such as dead-end filtration operate with feed flow and permeate flow in the same direction. Dead-end filtration creates a concentration of particles (filter cake) on the filter membrane (2). Figure 1 displays the comparison between traditional dead-end filtration and crossflow filtration.

\section{Dead-End Filtration}

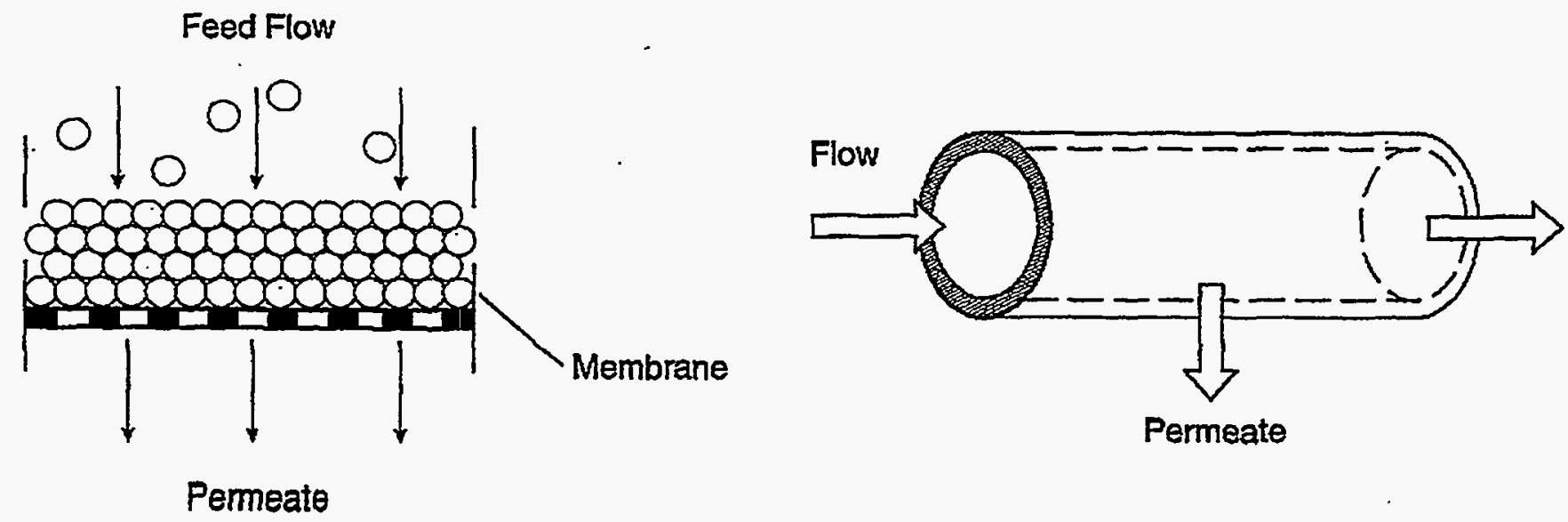

Figure 1. Comparison of traditional dead-end filtration with crossflow filtration (2). 


\section{THEORY}

With all forms of filtration, the greatest hindrance to liquid flow through the filter membrane is particle accumulation (filter cake). By utilizing a high-fluid circulation rate parallel to the filter membrane, the accumulation of particles on the filter surface can be minimized. Although crossflow filtration minimizes this accumulation, it does not eliminate it.

Several mechanisms are present in a crossflow filtration systems that affect filtrate flow. An excellent discussion by Geeting and Reynolds (3) explain the theory surrounding two mechanisms known as mass transport resistance and pressure filtration resistance, which are the two primary resistance's to filtrate flux.

Back transport of solids away from the membrane and into the bulk stream is required to prevent the cake thickness from continually increasing. Both a filter cake and boundary layer may be present in a crossflow filtration system. A schematic representation of crossflow filtration showing the filter membrane, the filter cake, the boundary layer and the bulk stream is shown in Figure 2.

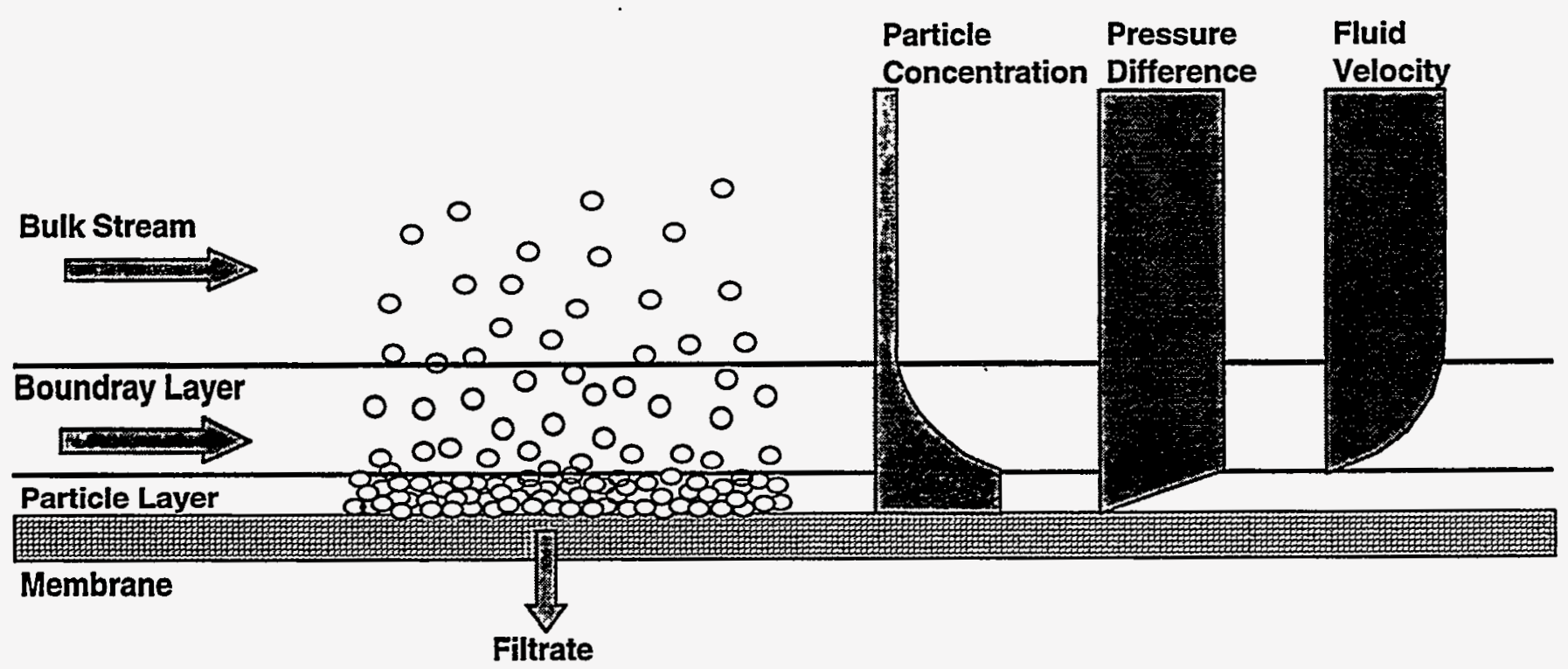

Figure 2. Schematic representation of Crossflow filtration showing the filter membrane, the filter cake, the boundary layer and the bulk stream. (Revised: Geeting, Reynolds 1996). 
If the limiting resistance to filtrate flux is due to the back transport of solids away from the membrane, then

$$
J_{m t}=k \ln \left(C_{w} / C_{b}\right)
$$

Where:

$J_{\mathrm{mt}}=$ Mass transfer limited flux,

$k=$ Back mass transfer coefficient

$\mathrm{C}_{\mathrm{w}}=$ Concentration at the wall

$\mathrm{C}_{b}=$ Concentration in the bulk stream

If mass transport does not limit filtrate flow, then filtrate flux should vary in accordance with Darcy's equation for pressure filtration.

$$
J_{f}=P / \mu\left(L / K+R_{m}\right)
$$

Where:

$J_{f}=$ pressure filtration limited flux $\left(\mathrm{m}^{3} / \mathrm{m}^{2 \star} \mathrm{S}\right)$

$\mathrm{P}=$ filtration pressure $(\mathrm{Pa})$

$\mu=$ Liquid viscosity ( $\left.\mathrm{Pa}^{\star} \mathrm{S}\right)$

$R_{m}=$ Filter media resitance $(1 / \mathrm{m})$

$L / K=$ filter cake resistance, where $L=$ cake thickness $(m)$ and $K=$ cake permeability $\left(m^{2}\right)$.

Equation 2 indicates the filtration rate $\mathrm{J}_{\mathrm{f}}$ increases when $\mathrm{P}$ increases, $\mathrm{K}$ increases, or $\mu$ decreases. The filtration rate $J_{f}$ decreases when $L$ increases, and $R_{m}$ increases. 
Two operational regimes exist for crossflow filtration. In the first regime, the filtrate flux is a function of pressure. In the second regime, it is not. These two regimes are described as follows.

Regime I- Suppose a given system at steady state with set axial velocity and constant filtration flux, $\mathrm{J}_{\mathrm{mt}}$ as described by Equation 1. If the filtration flux described by Equation 1 is greater than that described by Equation 2 (i.e., $J_{m t}>J_{f}$ ), then the filtrate flux will vary linearly with pressure because the flux will be limited as described by Darcy's filtration equation (equation 2). On the other hand, for the same system at set pressure with $J_{m t}>J_{f}$, an increase in velocity may or may not increase flux. An increase in axial velocity will not result in higher filtrate flux unless it causes the resistance to decrease (thus increasing $\mathrm{J}_{f}$ ). If the given axial velocity is effective at keeping the filter cake resistance low, axial velocity will not significantly effect filtrate flux.

Regime II- Given the same system described, with conditions such that $J_{m t}=J_{f}$. In this regime, the flux will no longer vary with pressure. Increased pressure will bring about an increase in cake resistance, $R_{c},(L / K)$ by means of growth in cake thickness or decrease in the cake permeability (or both). While an increase in pressure may cause $J_{m t}<J_{f}$ temporarily, velocity alone is effective in increasing the filtrate flux.

From equation 1 we see that increased solids in the feed, $C_{b}$, causes $J_{m t}$ to decrease. Therefore, increasing solids loading decreases the pressure at which $J_{m t}=J_{f}$, and a given system can switch from Regime I to Regime II merely by increasing the solids loading in the feed. 


\section{CELLS UNIT FILTER (CUF)}

A Cells Unit Filter (CUF) was fabricated at the Savannah River Site and transferred to the INEEL for testing in FY-97. During FY-97 testing, minor modifications were made to the CUF for operation in the Remote Analytical Laboratory (RAL) (1). No new modifications were made before FY-98 testing, other than the replacement of the filtrate measurement vessel that was damaged during storage.

The CUF consists mainly of stainless steel Swagelok fittings, valves and gauges. One 0.5-micron, 0.480 inch ID, 6-inch length Mott sintered Hastelloy filter element was used in the testing. A Moyno progressive cavity pump provided slurry feed solution, which is contained, within the slurry reservoir. Slurry temperature is measured by a type-J thermocouple installed in a thermowell within the slurry reservoir. A schematic of the CUF apparatus is shown in Figure 3.

Three sets of tests were performed with the CUF system. Each set consisted of a series of 13 experimental test conditions. Prior to each condition, two separate back pulses were performed at 45 and 70 psig. Back pulses were conducted by opening the V-3 back-pulse valve, filling the back-pulse chamber. The chamber is pressurized by opening the three-way V-7 back-pulse valve until the predetermined pressure is attained. The $V-7$ valve is then closed and the $V-3$ valve is opened allowing the pressurized filtrate to back pulse the filter.

At the completion of the second back pulse, a timer was started. Filtrate flow rates were measured by means of a fill-and-drain graduated cylinder. Filtrate flowrate measurements were taken in five-minute increments for a span of thirty minutes. Axial velocity, transmembrane pressure, filtrate flux and temperature data were also recorded . in addition to filtrate flow. Transmembrane pressure and axial velocity were controlled by adjusting the pump speed and the throttle valve (V1). Figure 4 displays a photograph of the CUF apparatus installed in the RAL. 


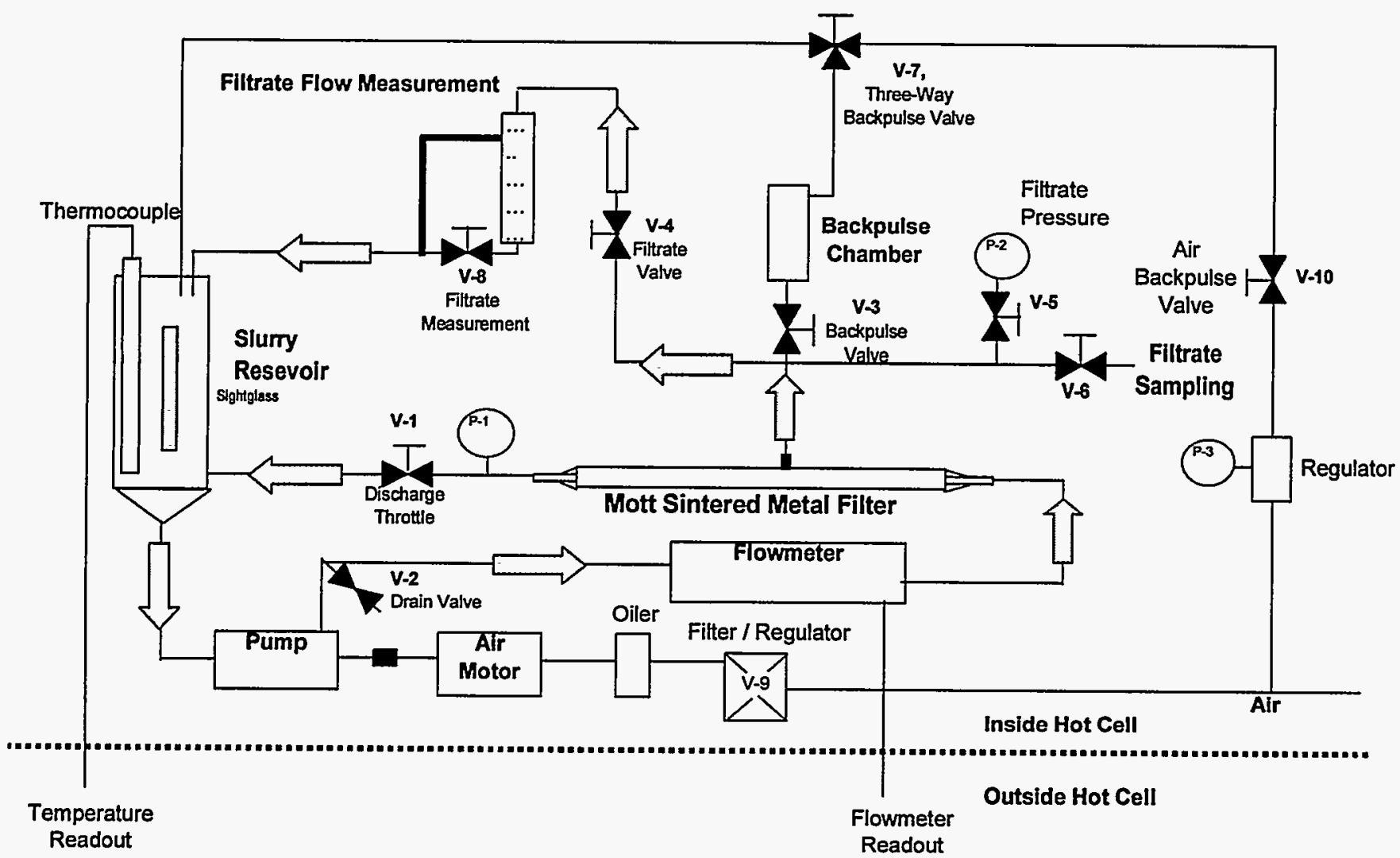

Figure 3. Schematic of the CUF apparatus (Tripp and Wade, 1997). 


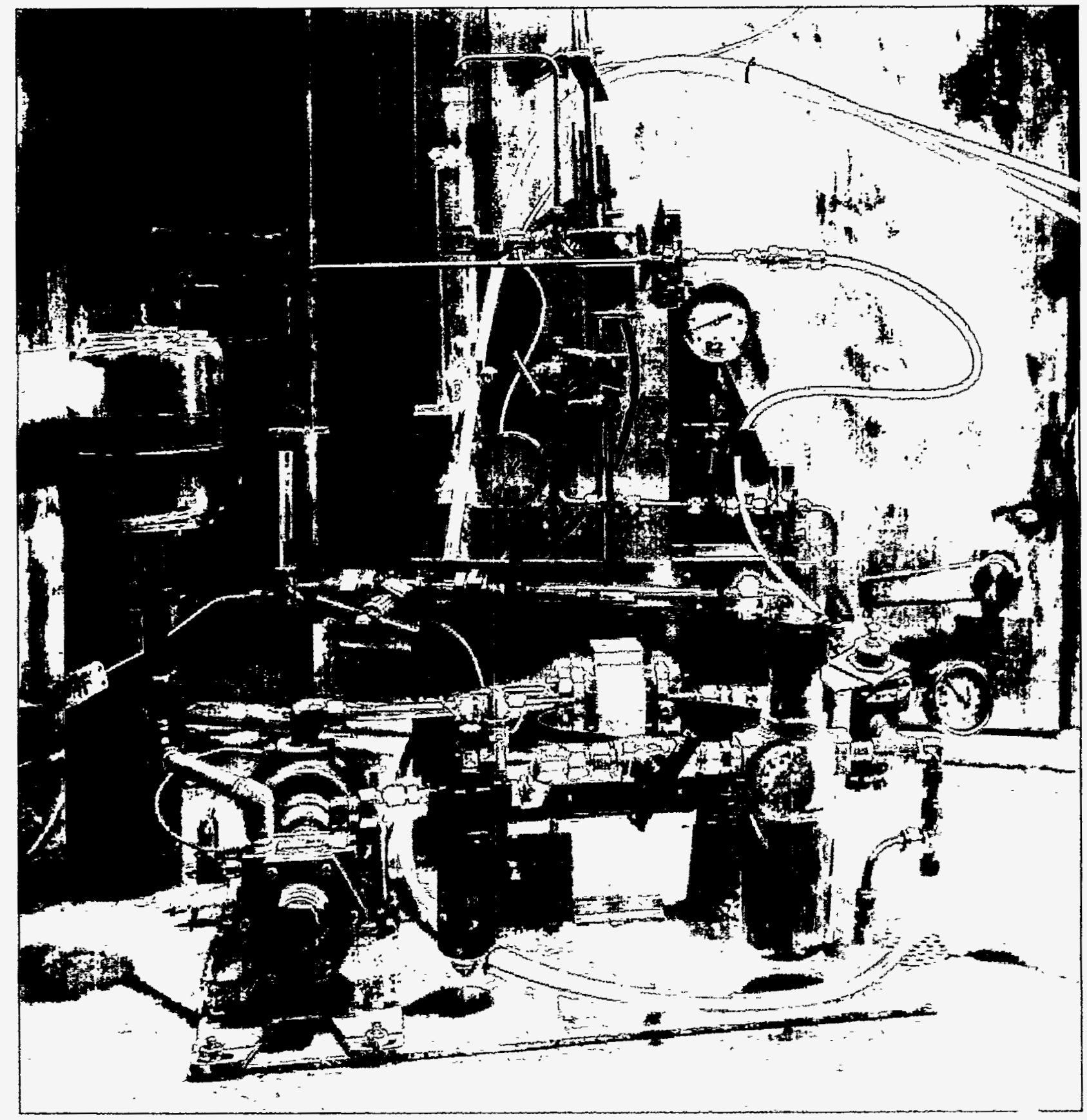

Figure 4. CUF installed in the Remote Analytical Laboratory. 


\section{EXPERIMENTAL PROCEDURE}

\section{TEST CONDITIONS}

Three sets of tests were performed with the CUF apparatus, each consisting of a series of 13 experimental test conditions. These test conditions were based on a Central Composite Response Surface Design first used by Hanford in their testing of the CUF apparatus (3). These test conditions were determined by selecting various axial velocities and transmembrane pressures. The initial conditions utilized by Hanford, consisted of only 11 test conditions. A modified version was created by adding two additional conditions at higher transmembrane pressures. These thirteen conditions were adopted from a previous CUF test performed at the INEEL (1).

Table 1 displays the various conditions and run order used in CUF testing at the INEEL. The center condition (1,6 and 11) was tested three times for the purpose of repeatability. Testing of the center condition assisted in the determination of filter fouling at a similar axial velocity and transmembrane pressure at various stages during the test (first, middle and last). The statistically designed experimental test conditions used in testing the CUF apparatus at the INEEL are shown in Figure 5.

Table 1. Conditions and run order used in testing of the CUF apparatus.

\begin{tabular}{ccc}
\hline Condition & Axial Velocity $(\mathrm{ft} / \mathrm{sec})$ & Transmembrane Pressure $(\mathrm{psig})$ \\
\hline 1 & 6.0 & 20.0 \\
2 & 7.5 & 27.5 \\
3 & 3.0 & 20.0 \\
4 & 6.0 & 5.0 \\
5 & 7.5 & 12.5 \\
6 & 6.0 & 20.0 \\
7 & 4.5 & 27.5 \\
8 & 6.0 & 35.0 \\
9 & 4.5 & 12.5 \\
10 & 9.0 & 20.0 \\
11 & 6.0 & 20.0 \\
12 & 6.0 & 45.0 \\
13 & 6.0 & 55.0 \\
\hline
\end{tabular}




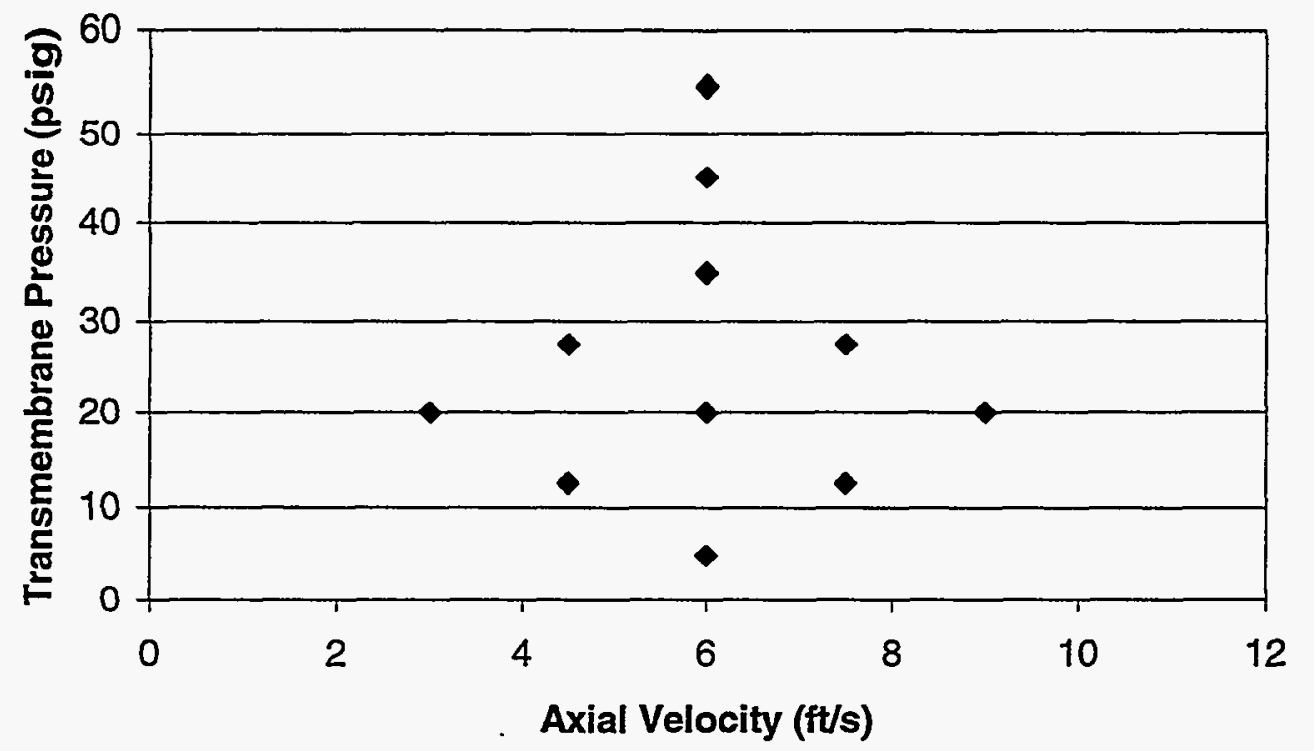

Figure 5. Statistically designed experimental test conditions.

\section{BASELINE WATER RUN CONDITIONS}

Baseline water runs were performed prior to the testing of actual and simulated waste slurries. Baseline water runs assisted in the determination of filter fouling between actual waste slurries. Approximately $800 \mathrm{mLs}$ of deionized water, free from any solids, were utilized for individual water runs. Nine test conditions were performed in succession excluding conditions 6 and 11, which are analogous to condition 1. Preceding each water run, the CUF unit was extensively rinsed (including several back pulses) with deionized water until no solids were collected from the rinse solution. The nine experimental baseline water run test conditions are shown in Table 2.

The order in which baseline water runs were performed is as follows: Water run 1, was performed in FY-97, prior to testing of actual tank waste (1). A new Hastelloy filter was installed on the CUF unit prior to this testing. Water run 2 was performed prior to testing in FY-98. Water run 3 was performed following the test of actual dissolved $\mathrm{H}-4$ calcine slurries. Water run 4 was performed following the test of dissolved Run 1027 calcine slurries. 
Table 2. Nine experimental baseline water run test conditions.

\begin{tabular}{ccc} 
Condition & Axial Velocity (ft/sec) & Transmembrane Pressure (psig) \\
\hline $1,6,11$ & 6.0 & 20.0 \\
2 & 7.5 & 27.5 \\
3 & 3.0 & 20.0 \\
4 & 6.0 & 5.0 \\
5 & 7.5 & 12.5 \\
7 & 4.5 & 27.5 \\
8 & 6.0 & 35.0 \\
9 & 4.5 & 12.5 \\
10 & 9.0 & 20.0 \\
\hline
\end{tabular}

\section{FEED SOLUTIONS}

Two slurry feed solutions were utilized in the testing of the CUF apparatus. The first test was performed using radioactive dissolved $\mathrm{H}-4$ calcine. One hundred and ninety one (191) grams of $\mathrm{H}-4$ calcine were dissolved in various molar concentrations of nitric acid. At $98.2 \%$ dissolution, 3.44 grams of UDS remained. Eight hundred and thirty-one (831) $\mathrm{mLs}$ of actual dissolved $\mathrm{H}-4$ calcine were used in testing of the CUF unit. Initial UDS present in solution were filtered and dried during dissolution studies. Initial recovered UDS, weighing 1.99 grams, were reintroduced into solution. The concentration of UDS in solution was 0.19 weight percent. The composition of the dissolved $\mathrm{H}-4$ calcine solution used in testing of the CUF is shown in Table 3.

The second test was performed using the same dissolved $\mathrm{H}-4$ calcine slurry with additional UDS. To increase solids loading, an additional 23.06 grams of Run 74 UDS were added to the previous solution containing 1.99 grams. Additional UDS were obtained at the completion of non-radioactive Run 74 calcine dissolution studies. The combined concentration of UDS in solution was 2.44 weight percent.

The third and final test was performed using non-radioactive pilot plant dissolved Run 1027 calcine. This solution was utilized due to the low percent of solids that will dissolve in solution and the limited availability of actual calcine UDS precluded testing at higher waste loadings (>0.2 wt \%). Approximately 200 grams of Run 1027 pilot plant calcine was dissolved in 1000-mLs of $5 \mathrm{M}$ nitric acid. At $60 \%$ dissolution, 80.08 grams of UDS remained. Approximately $800-\mathrm{mLs}$ of dissolved Run 1027 calcine slurry were utilized for testing of the CUF unit.

The concentration of solids in solution was 7.94 weight percent. Table 4 displays the composition of the dissolved Run 1027 calcine solution (5). 
Table 3. Composition of dissolved $\mathrm{H}-4$ calcine solution.

\begin{tabular}{lll}
\hline Component & $\mu \mathrm{g} / \mathrm{ml}$ & $M$ \\
\hline $\mathrm{Al}$ & 29208.1 & 1.08 \\
$\mathrm{Ca}$ & 6929.3 & 0.172 \\
$\mathrm{Cr}$ & 210.7 & $4.05 \mathrm{E}-3$ \\
$\mathrm{Fe}$ & 986.0 & $1.76 \mathrm{E}-2$ \\
$\mathrm{~Pb}$ & 67.5 & $3.25 \mathrm{E}-4$ \\
$\mathrm{Hg}$ & 5.72 & $2.85 \mathrm{E}-5$ \\
$\mathrm{Ni}$ & 110.0 & $1.87 \mathrm{E}-3$ \\
$\mathrm{~K}$ & 1280.0 & $3.27 \mathrm{E}-2$ \\
$\mathrm{Na}$ & 4020.0 & 0.1748 \\
$\mathrm{Sr}$ & 8.99 & $1.02 \mathrm{E}-4$ \\
$\mathrm{Zr}$ & 325.51 & $3.56 \mathrm{E}-3$ \\
\hline
\end{tabular}


Table 4. Composition of non-radioactive pilot plant dissolved Run1027 calcine (4).

\begin{tabular}{lll}
\hline Component & $\mu \mathrm{g} / \mathrm{ml}$ & $M$ \\
\hline Acid & $\mathrm{N} / \mathrm{A}$ & 3.243 \\
$\mathrm{Al}$ & 14900 & 0.552 \\
$\mathrm{~B}$ & 136 & 0.0125 \\
$\mathrm{Ca}$ & 3690 & 0.0921 \\
$\mathrm{~F}$ & $\mathrm{~N} / \mathrm{A}$ & $<0.0026$ \\
$\mathrm{Fe}$ & 33.4 & $6.0 \mathrm{E}-4$ \\
$\mathrm{NO}{ }_{3}^{-}$ & $\mathrm{N} / \mathrm{A}$ & 4.62 \\
$\mathrm{~K}$ & 20 & $5.1 \mathrm{E}-4$ \\
$\mathrm{Na}$ & 200 & 0.0087 \\
$\mathrm{Sr}$ & 7.42 & $8.5 \mathrm{E}-5$ \\
$\mathrm{Zr}$ & $<0.03$ & $<3 \mathrm{E}-7$ \\
\hline
\end{tabular}




\section{RESULTS AND DISCUSSION}

\section{BASELINE WATER RUN RESULTS}

The filtrate flowrate $(\mathrm{mL} / \mathrm{sec}$ ) for each of the 9 conditions performed is shown in Figure 6 . The filtrate flowrate $(\mathrm{mL} / \mathrm{sec})$ is plotted against the 9 test conditions. Relatively high filtrate flowrates were observed for water run 1. This was expected, due to the installation of a new Hastelloy filter prior to testing. Higher filtrate flowrates can be observed at higher transmembrane pressures, such as conditions 2, 7 and 8 . Lower filtrate flowrates are observed in conditions with a lower transmembrane pressure. These results confirm the Hagen-Poiseuille Equation, which accurately predicts clean water flux through cylindrical pores (6).

$$
\eta=\pi r^{2} \Delta p t / 8 V L
$$

Where:

$\eta=$ Shear viscosity

$\pi=3.1415926$

$\Delta \mathrm{p}=$ Pressure drop

$t=$ Time it takes for a $V$ volume of liquid to flow through a capillary of length $L$ $r=$ Pore radius

The equation states that liquid flux is proportional to the transmembrane pressure and inversely proportional to the liquid viscosity, which is controlled by the solute concentration and the temperature. Therefore, increasing the pressure or the temperature results in an increase in flux (6).

Filtrate flowrate values for baseline water runs 2, 3 and 4 are substantially lower compared to flowrates shown in water run 1. Back pulsing was unsuccessful at restoring the filtrate flowrate to the original values shown in water run 1. It is apparent that particles within the pores of the filter membrane were not removed, despite extensive rinsing and backpulsing. 


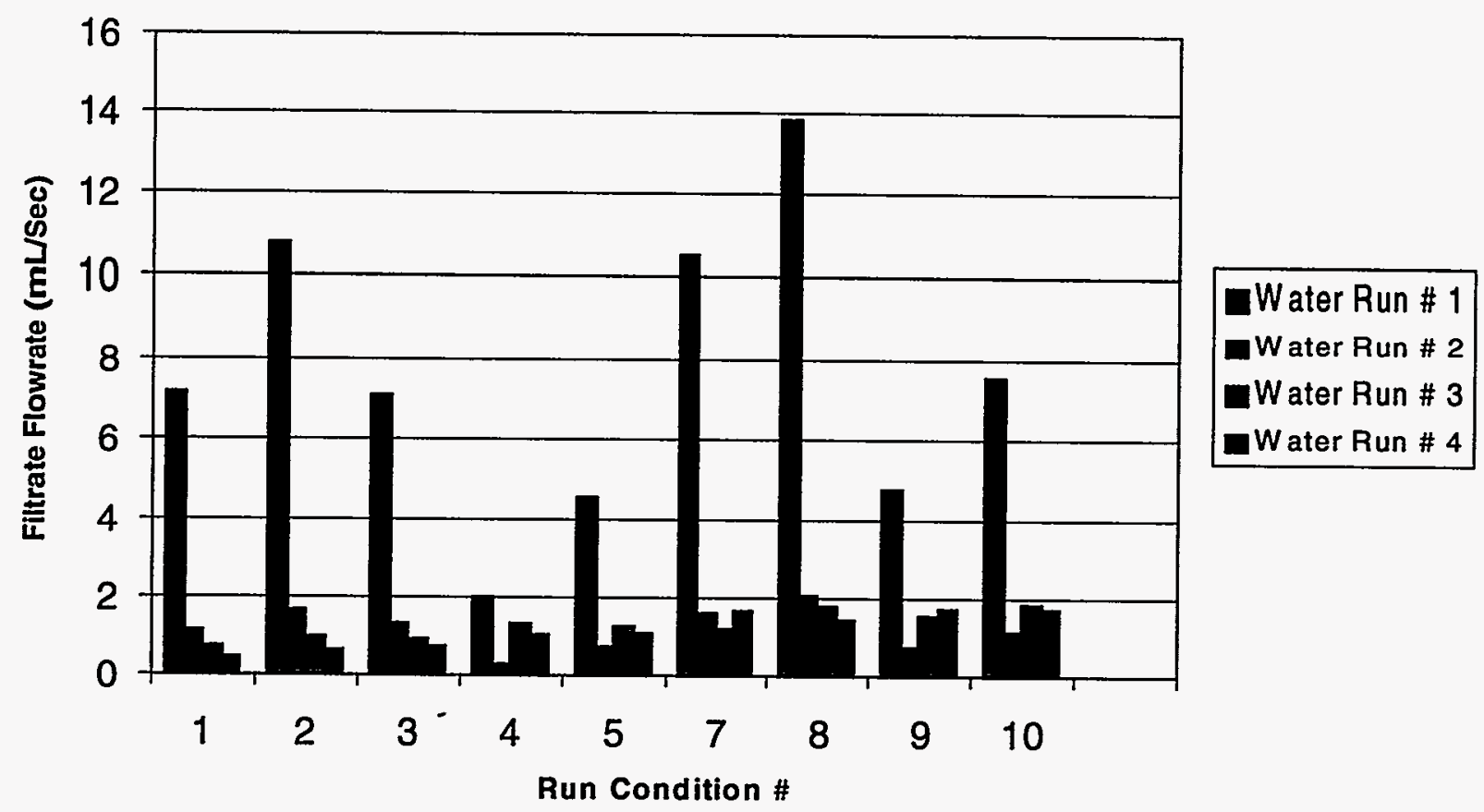

Figure 6. Filtrate flowrate $(\mathrm{mL} / \mathrm{sec})$ for each of the 10 conditions tested.

\section{DISSOLVED H-4 CALCINE (0.19 wt\%)}

Figure 7 displays the filtrate flux $\left(\mathrm{gpm} / \mathrm{ft}^{2}\right)$ for conditions 1 through 13 as a function of time (minutes) since back pulse. A substantial decrease in flux is observed through the first 5 minutes, after which the rate of decline lessens substantially. Steady state is achieved at approximately 25 minutes since back pulse. Back pulses prior to each condition appear to restore filtrate flux, however, considerable filter fouling is observed within 5 minutes after back pulse. The rate of filter cake accumulation is slightly less than rates observed at higher solids loadings. At twenty minutes from back pulse, an increase in flux is observed for conditions 4 and 13. One theory, which might explain the random increase in flux, is the accumulation and dispersion of particles on the needle valve $(V-1)$. 


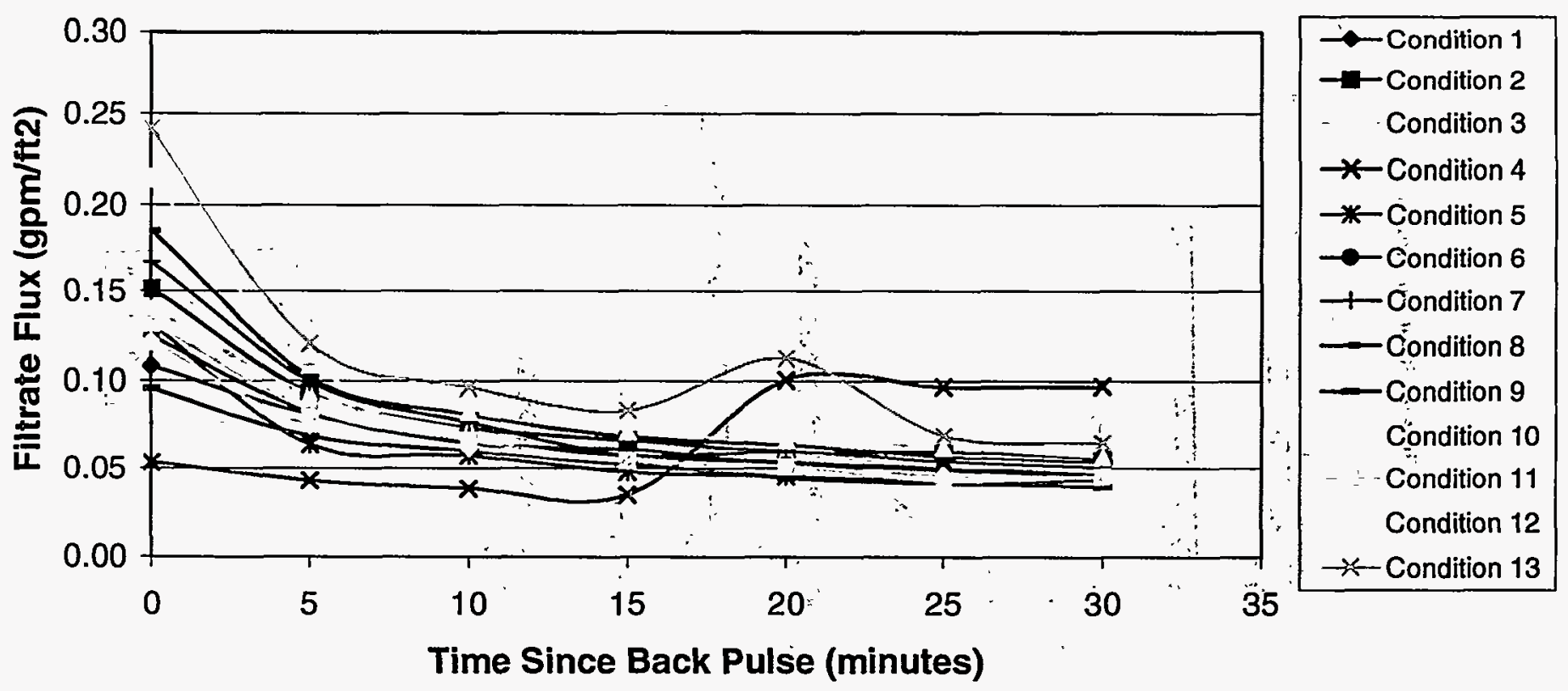

Figure 7. Filtrate flux as a function of time since back pulse for conditions 1 through 13 at 0.19 weight percent solids loading. 
Figure 8 displays the filtrate flux as a function of time (minutes) since back pulse for conditions 1, 6 and 11, all tested at $6 \mathrm{ft} / \mathrm{s}$ axial velocity and $20 \mathrm{psig}$ transmembrane pressure. Filtrate flux values appear to be very similar, despite a slight variance in initial flux. Filtrate flux values for conditions 6 and 11 are shown slightly higher than condition 1 at time zero. This would suggest inconsistent backpulse techniques. This theory is confirmed by the union of all three conditions at five minutes since backpulse.

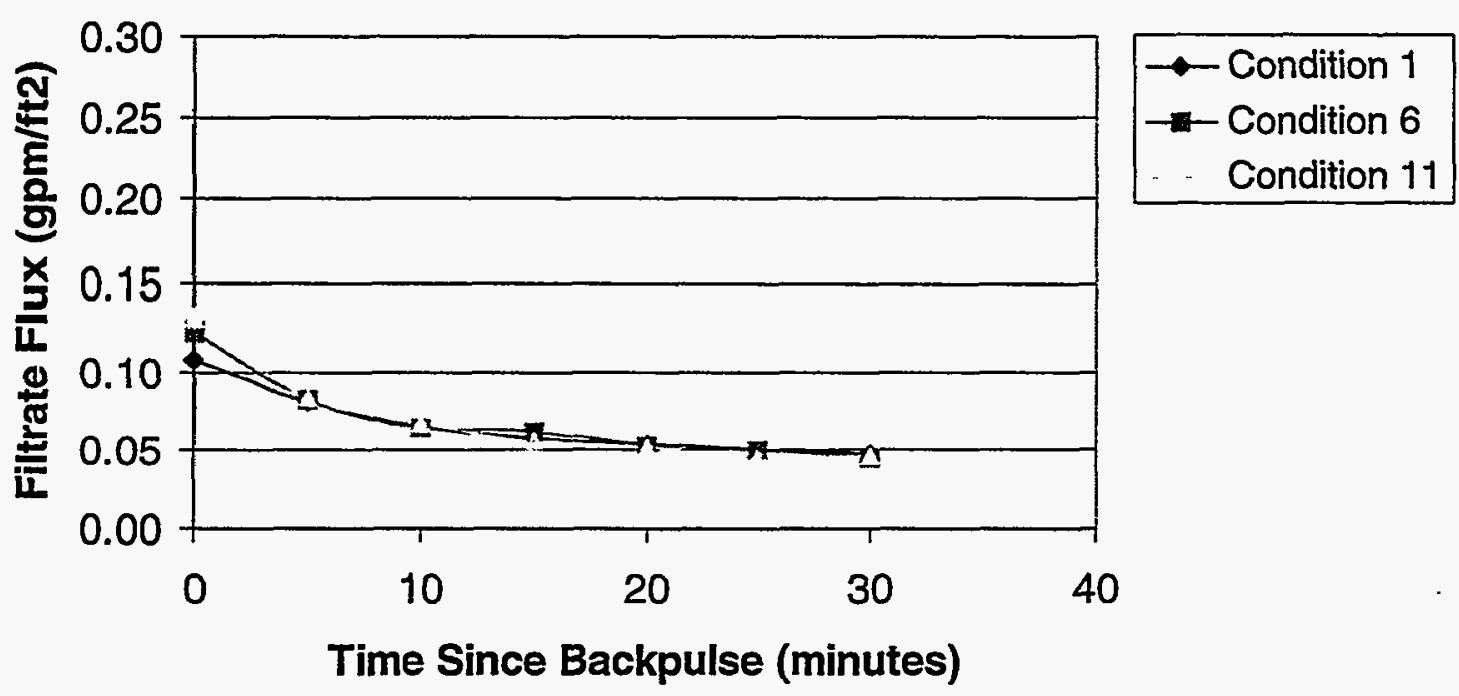

Figure 8. Filtrate flux as a function of time since backpulse for conditions 1,6 and 11 , at 0.19 weight percent solids loading. 
Figure 9 displays filtrate flux $\left(\mathrm{gpm} / \mathrm{ft}^{2}\right)$ as a function of transmembrane pressure (psig) for 0.19 weight percent solids loading. Average filtrate flux and transmembrane values were applied using only those conditions operating at $6 \mathrm{ft} / \mathrm{s}$ axial velocity. Filtrate flux values are approximately linear with transmembrane pressure indicating that mass transport does not limit filtrate flux. Filtrate flux is pressure dependent as described by Darcy's filtration equation (Equation 2).

Figure 10 displays the filtrate flux $\left(\mathrm{gpm} / \mathrm{ft}^{2}\right)$ as a function of axial velocity $(\mathrm{ft} / \mathrm{s})$ for 0.19 weight percent solids loading. Average filtrate flux values were applied using only those conditions operating at 20 psig transmembrane pressure. Inspection of Figure 10 indicates that filtrate flux is inversely proportional to axial velocity. Increases in axial velocity would not increase filtrate flux. It is possible that very little cake resistance is present. This could be a factor of two things: 1) low solids loading in solution, or 2) axial velocities sufficient at keeping filter cake resistance low. 


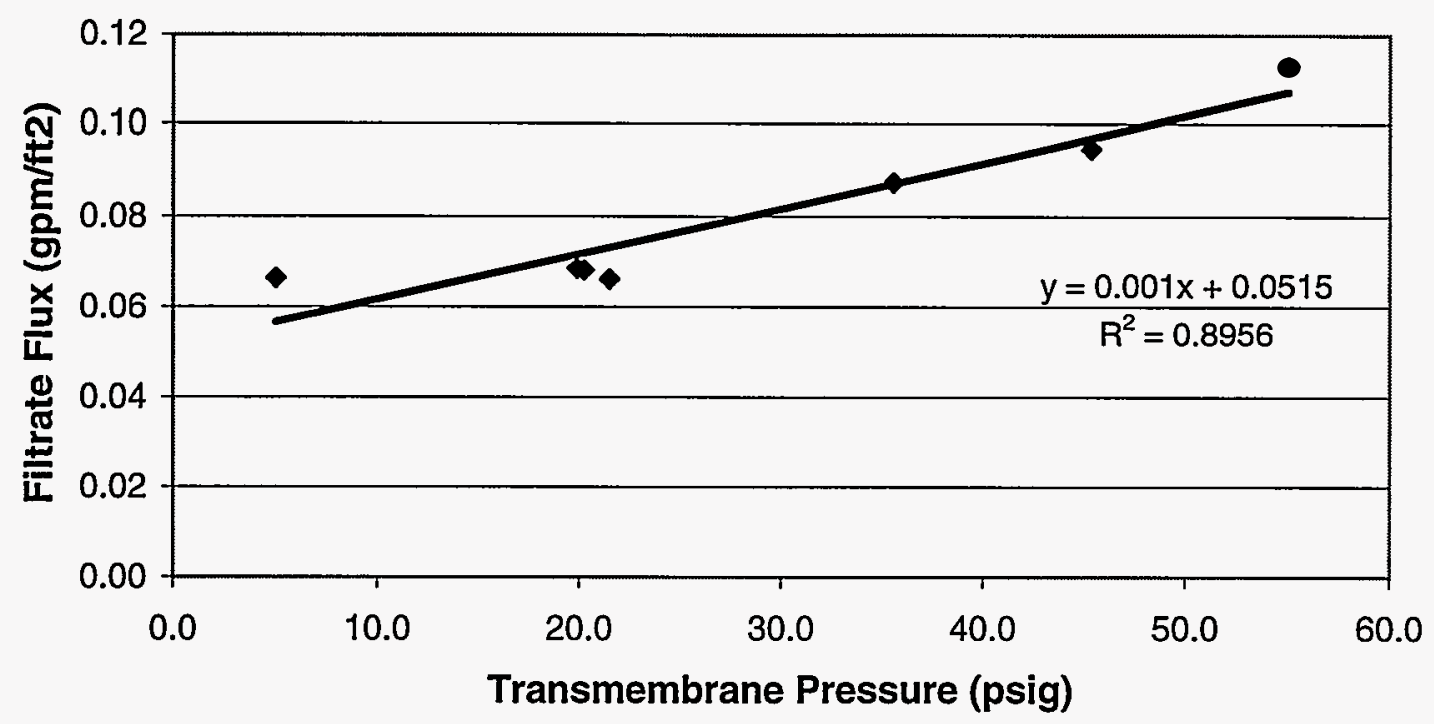

Figure 9. Filtrate flux as a function of transmembrane pressure at $3.7 \mathrm{gpm}$ (averages) for 0.19 wt percent solids loading.

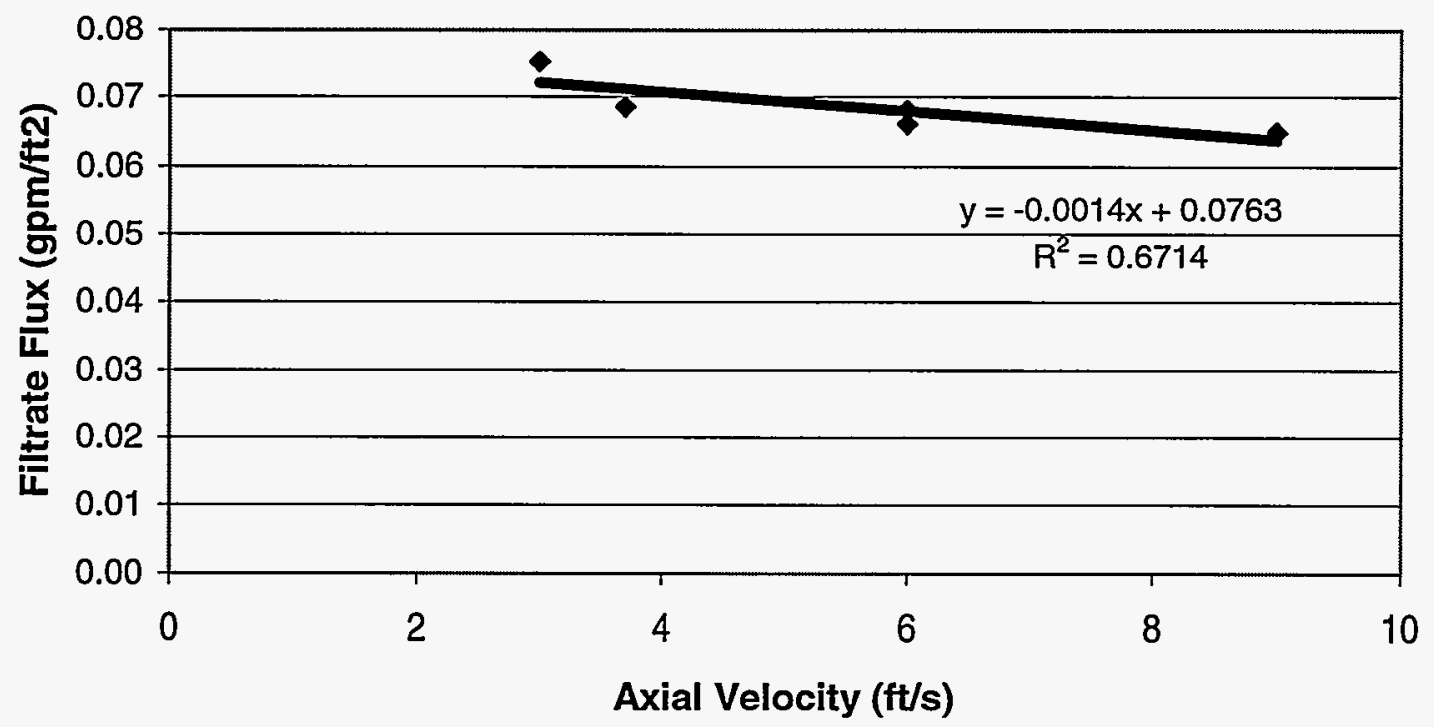

Figure 10. Filtrate flux as a function of axial velocity at $20 \mathrm{psig}$ (averages) for 0.19 weight percent solids loading. 


\section{DISSOLVED H-4 CALCINE (2.44 wt\%)}

Figure 11 displays the filtrate flux (gpm/ $\left./ \mathrm{t}^{2}\right)$ for conditions 1 through 13 as a function of time (minutes) since backpulse. A distinct decrease in flux is observed through the first 5 minutes, after which the rate of decrease lessens. Steady state is achieved at approximately 20 minutes since backpulse. Back pulsing prior to each condition appears to restore filtrate flux, however flux quickly diminishes. Steady state is achieved sooner than with the lower solids loading of 0.19 weight percent. This would indicate that the formation of the filter cake is achieved much sooner compared to lower solids loadings.

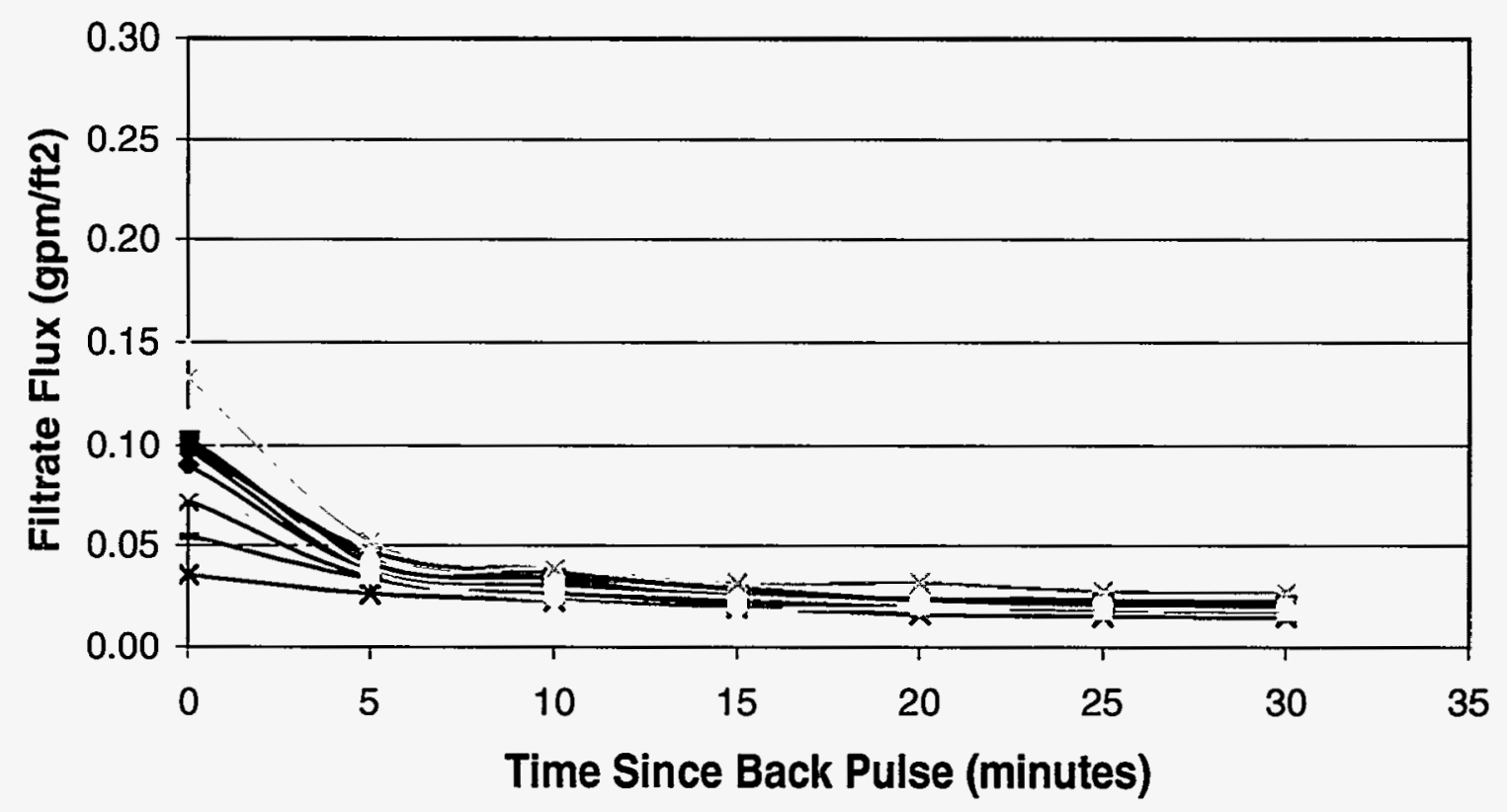

$\rightarrow-$ Condition 1

$\rightarrow$-Condition 2 Condition 3

$\rightarrow$ Condition 4

$\rightarrow$ - Condition 5

$\rightarrow-$ Condition 6

$\rightarrow$ Condition 7

- Condition 8

- Condition 9

Condition 10

Condition 11 Condition 12

$\therefore$ Condition 13

35

Figure 11. Filtrate flux as a function of time since backpulse for conditions 1 through 13 at 2.44 weight percent solids loading. 
Figure 12 displays the filtrate flux as a function of time (minutes) since backpulse for conditions 1, 6 and 11 all tested at $6 \mathrm{ft} / \mathrm{s}$ axial velocity and $20 \mathrm{psig}$ transmembrane pressure. Filtrate flux values appear to be very similar, despite a slight variance in initial flux. Similar variations were observed in testing at 0.19 weight percent. Filtrate flux values for condition 6 are slightly higher than condition 1 at time zero. This would suggest inconsistent backpulse techniques. This theory is confirmed by the union of all three conditions at approximately five minutes since backpulse.

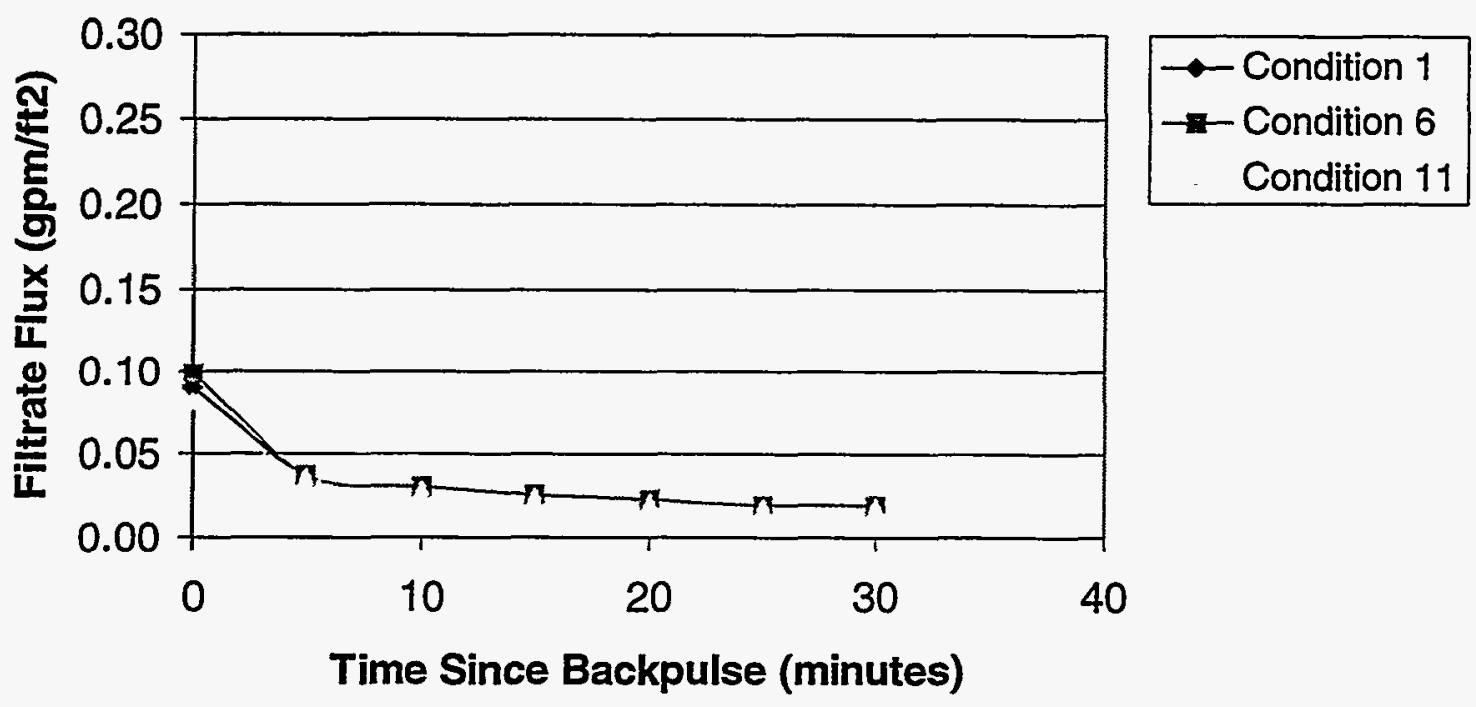

Figure 12. Filtrate flux as a function of time since backpulse for conditions 1,6 and 11 at 2.44 weight percent solids loading. 
Figure 13 displays filtrate flux $\left(\mathrm{gpm} / \mathrm{ft}^{2}\right)$ as a function of transmembrane pressure (psig) for 2.44 weight percent solids loading. Average filtrate flux and average transmembrane pressure values were applied using only those conditions operating at 6 $\mathrm{ft} / \mathrm{s}$ axial velocity. The filtrate flux is approximately linear with transmembrane pressure, indicating that filtrate flux is pressure dependent, as described by Darcy's filtration equation. However, it should be noted that the slope of filtrate flux as a function of transmembrane pressure greatly decreases with additional solids loading. This would indicate that at higher solids loadings, filtrate flux is less dependent on transmembrane pressure.

Figure 14 displays a plot of filtrate flux $\left(\mathrm{gpm} / \mathrm{ft}^{2}\right)$ as a function of axial velocity (ft/s) for 2.44 weight percent solids loading. Average filtrate flux values were applied using only those conditions operating at 20 psig transmembrane pressure. Inspection of Figure 14 indicates that filtrate flux is inversely proportional to axial velocity. An increase in axial velocity would not increase filtrate flux. It should also be noted that the slope of filtrate flux as a function of axial velocity gradually decreases with increased solids loading. 


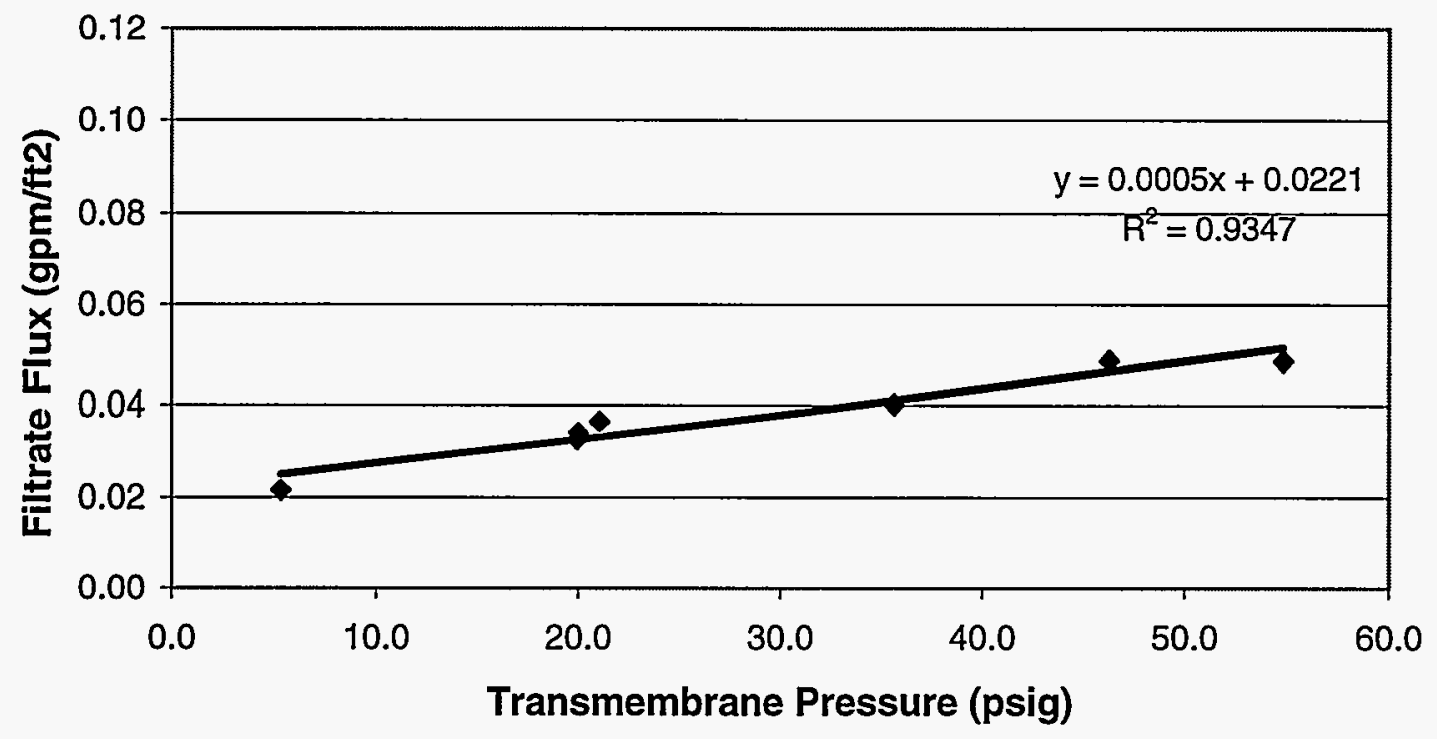

Figure 13. Filtrate flux as a function of transmembrane pressure at $3.7 \mathrm{gpm}$ (averages) for 2.44 weight percent solids loading.

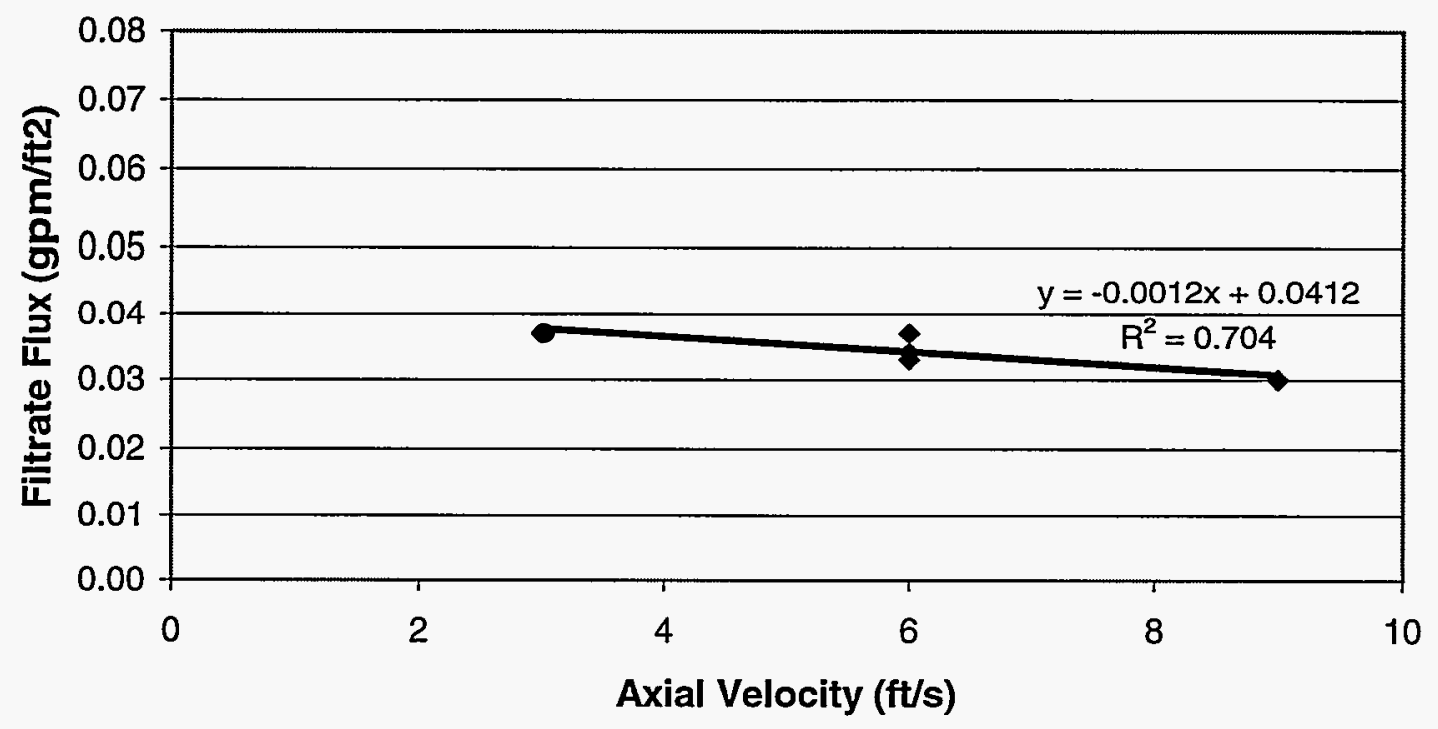

Figure 14. Filtrate flux as a function of axial velocity at $20 \mathrm{psig}$ (averages) for 2.44 weight percent solids loading. 


\section{NON-RADIOACTIVE DISSOLVED RUN 1027 PILOT PLANT CALCINE (7.94 wt\%)}

Figure 15 displays the filtrate flux ( $\left(\mathrm{gpm} / \mathrm{ft}^{2}\right.$ ) for conditions 1 through 13 as a function of time (minutes) since backpulse. A substantial decrease in flux is observed through the first 5 minutes, after which a steady state is achieved. Steady state is achieved sooner than with previous tests at lower solids loading. This would indicate that formation of filter cake is achieved sooner compared to lower solids loading. Back pulsing prior to each condition appears to restore filtrate flux; however, severe filter fouling is evident after five minutes since backpulse.

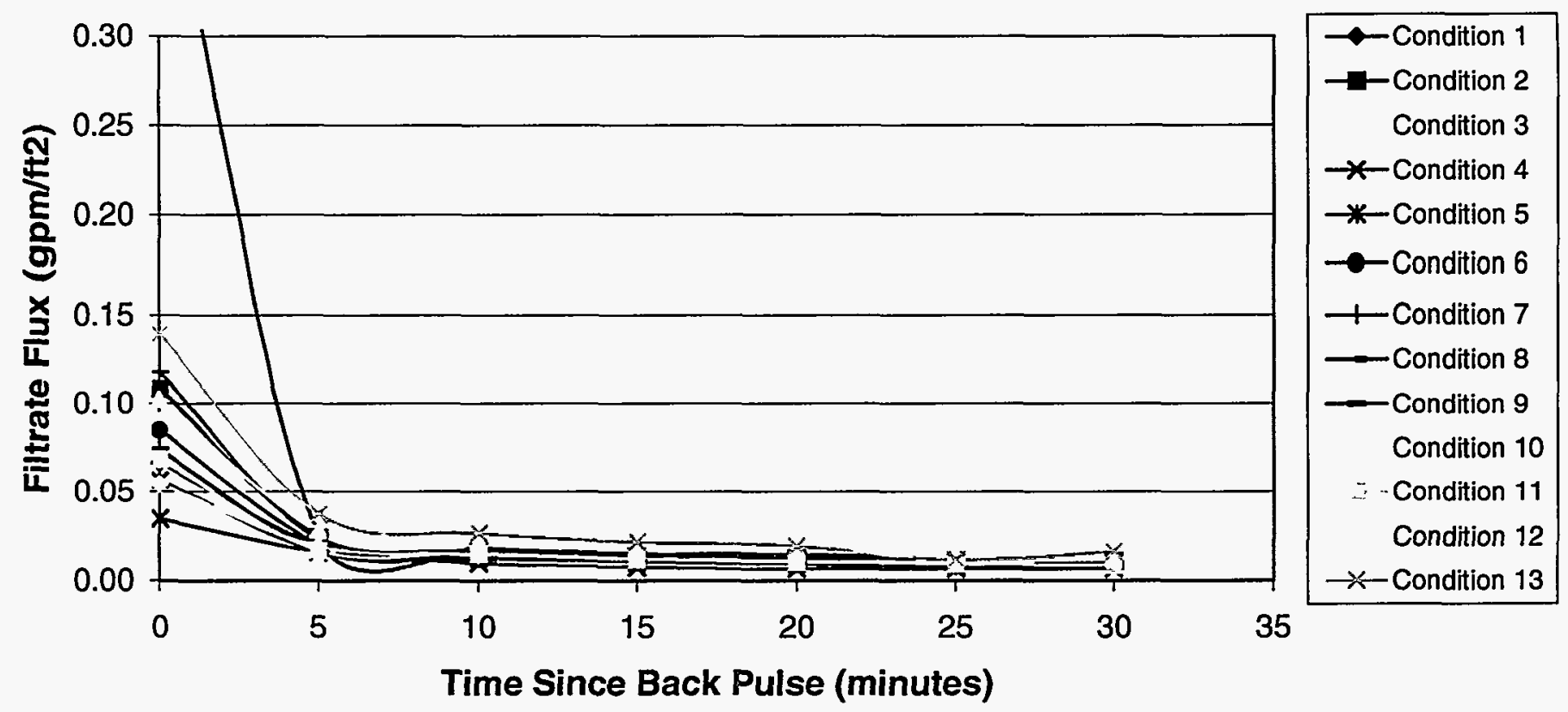

Figure 15. Filtrate flux as a function of time since backpulse for conditions 1 through 13 at 7.94 weight percent solids loading. 
Figure 16 displays filtrate flux as a function of time (minutes) since backpulse for conditions 1,6 and 11 , all tested at $6 \mathrm{ft} / \mathrm{s}$ axial velocity and $20 \mathrm{psig}$. Filtrate flux rates for conditions 6 and 11 are shown slightly higher than condition 1 at time zero. This would suggest inconsistent backpulse techniques. This theory is confirmed by the union of all three conditions at five minutes since backpulse. Similar variations observed during testing of 0.19 and 2.44 weight percent solids loading imply inconsistent backpulse techniques performed for all tests. Despite variations of filtrate flux, backpulses appear to restore filter performance. Nevertheless, increased filtrate flux could be achieved by optimizing backpulse techniques.

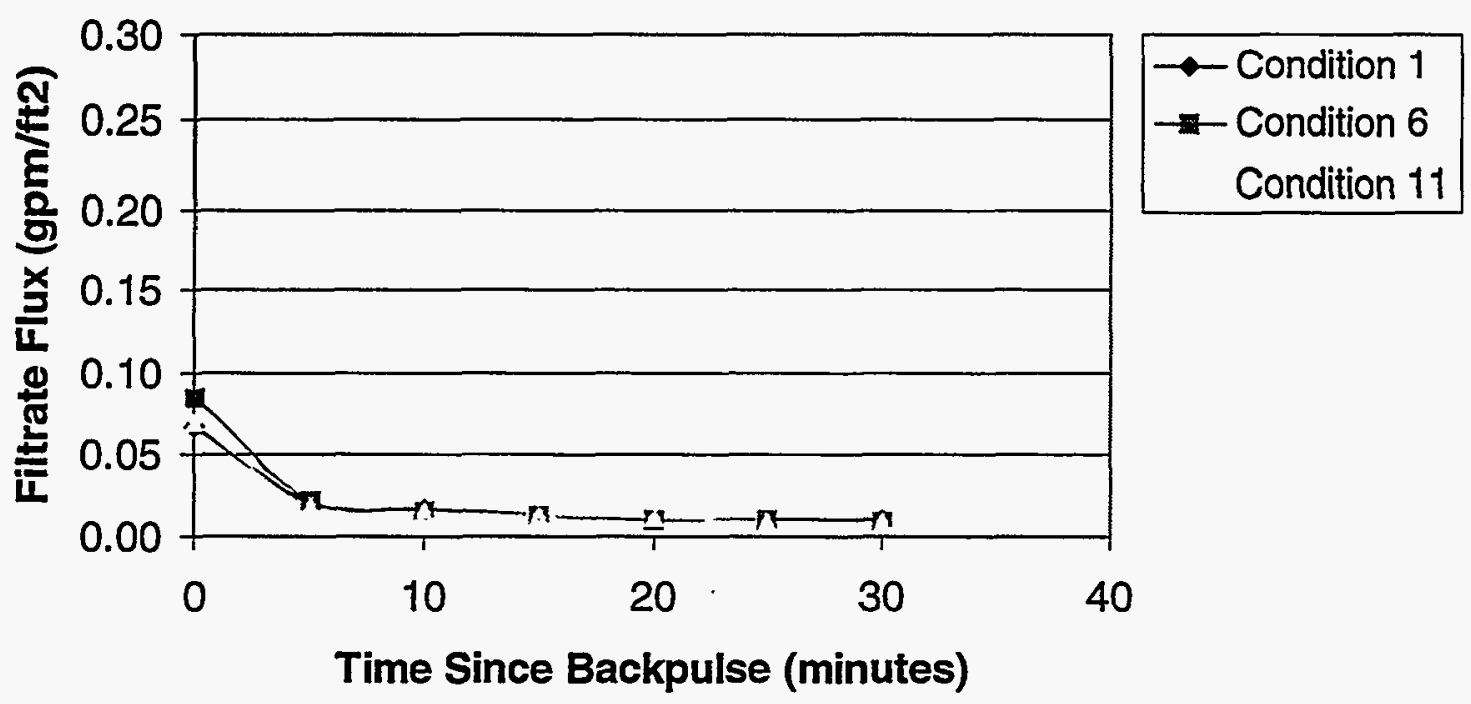

Figure 16. Filtrate flux as a function of time since backpulse for conditions 1,6 and 11 at 7.94 weight percent solids loading. 
Figure 17 displays filtrate flux $\left(\mathrm{gpm} / \mathrm{tt}^{2}\right)$ as a function of transmembrane pressure (psig) for 7.94 weight percent solids loading. Average filtrate flux and average transmembrane pressure values were applied using only those conditions operating at 6 $\mathrm{ft} / \mathrm{s}$ axial velocity. Filtrate flux values are approximately linear with transmembrane pressure, indicating that mass transport does not limit filtrate flux. Filtrate flux is pressure dependent as described by Darcy's filtration equation (Equation 2). The curve fit equation displays a low slope value, indicating that filtrate flux is less dependent on transmembrane pressure compared to lower solids loadings.

Figure 18 displays the filtrate flux $\left(\mathrm{gpm} / \mathrm{ft}^{2}\right)$ as a function of axial velocity $(\mathrm{ft} / \mathrm{s})$ for 7.94 weight percent solids loading. Average filtrate flux values were applied using only those conditions operating at $20 \mathrm{psig}$ transmembrane pressure. The negative slope indicates that filtrate flux is inversely proportional to velocity. An increase in axial velocity would not result in a higher filtrate flux unless it causes the resistance to decrease. Axial velocities present are sufficient at removing filter cake even at higher solids loadings (7). 


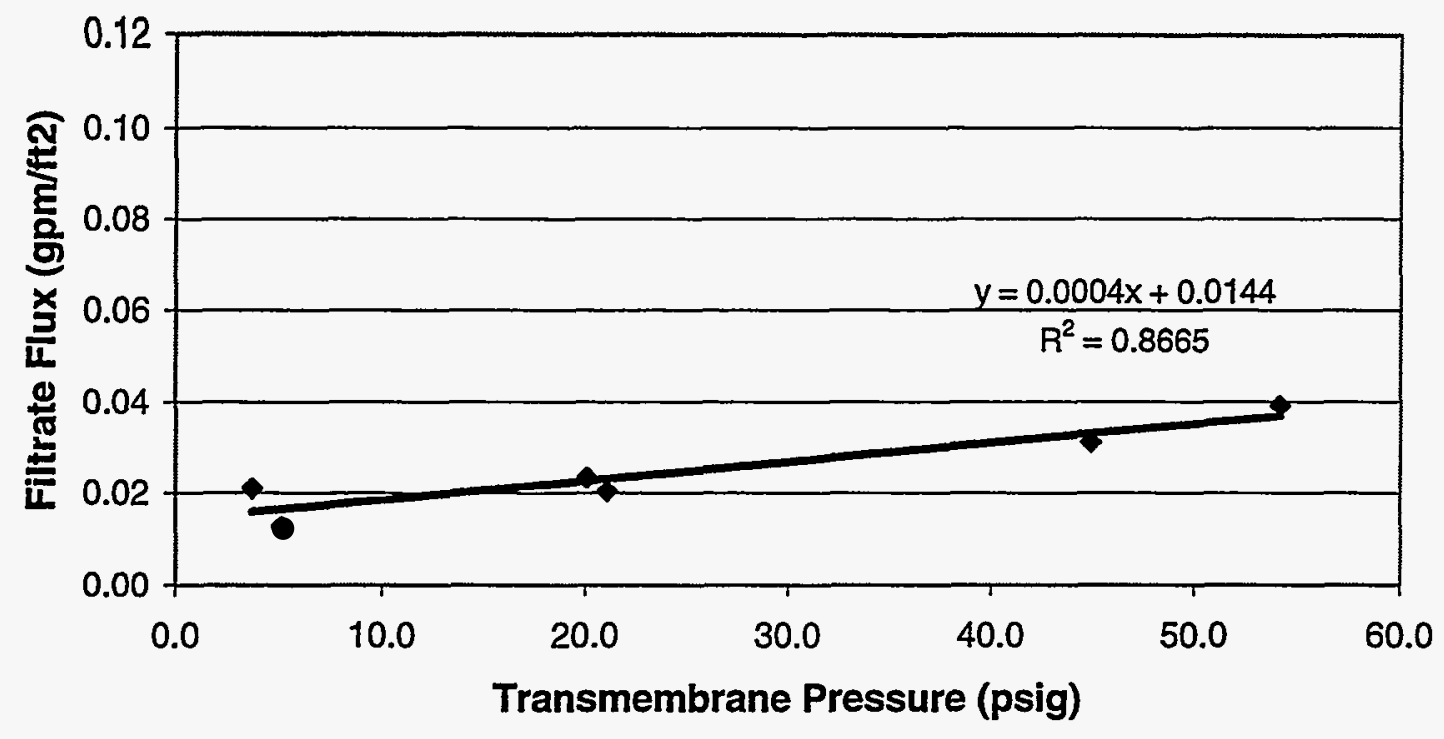

Figure 17. Filtrate flux as a function of transmembrane pressure at $3.7 \mathrm{gpm}$ (averages) for 7.94 weight percent solids loading.

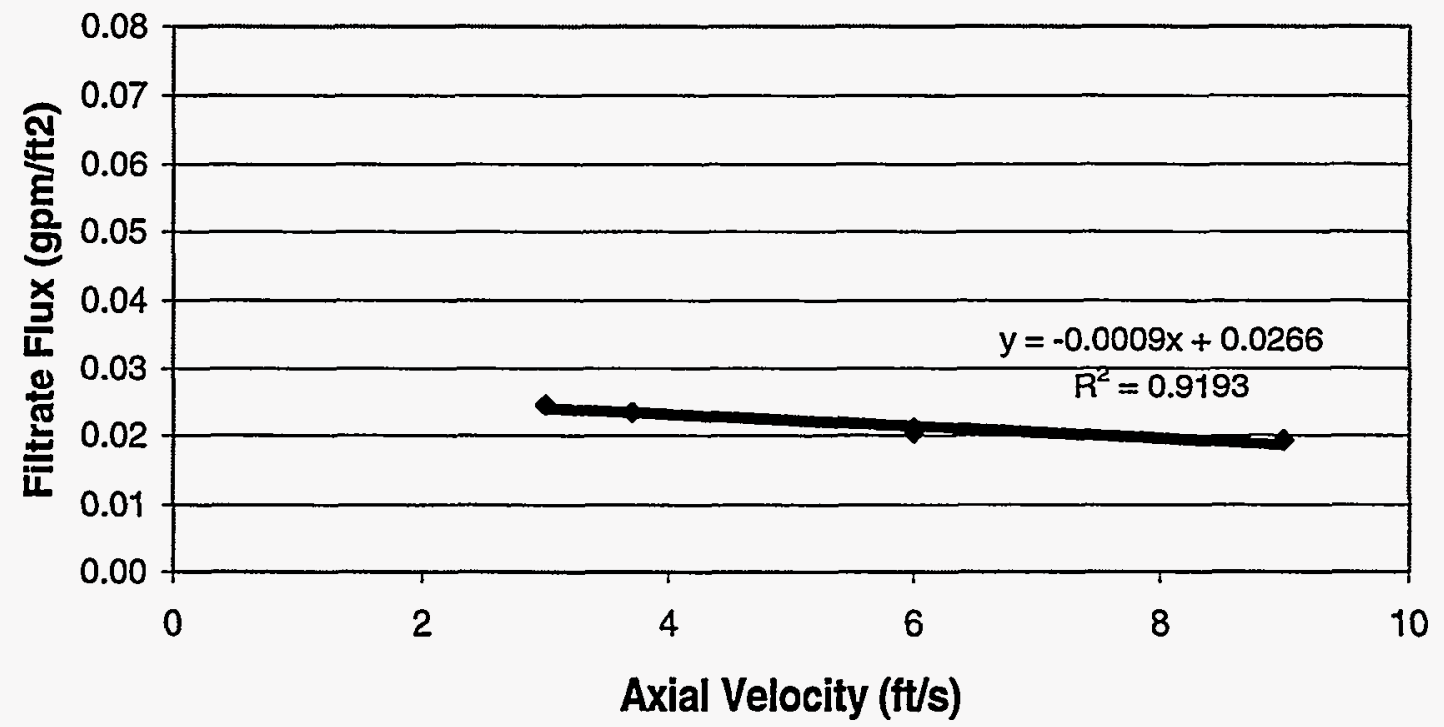

Figure 18. Filtrate flux as a function of axial velocity at $20 \mathrm{psig}$ (averages) for 7.94 weight percent solids loading. 


\section{SOLIDS LOADING COMPARISON}

Figure 19 displays the filtrate flux as a function of transmembrane pressure for $0.19,2.44$ and 7.94 weight percent solids loading, respectively. The filtrate flux dependence on transmembrane pressure is approximately linear for all solids loadings, specifying the operating regime as Regime I. A decrease of both slope and filtrate flux are observed with the increased solids loading. A gradual decrease of transmembrane pressure dependence can be observed with increased solids loading. These data suggest a gradual transition from Regime I to Regime II. From Equation 1, increased solids in the feed, $C_{b}$ causes $J_{m t}$ to decrease. Therefore, increasing solids loading decreases the pressure at which $J_{m t}=J_{f}$ and a given system can switch from Regime I to Regime II by simply increasing solids loading in the feed (3). Additional increases in solids loading would incite the critical value at which the filtrate flux looses its dependence on pressure.

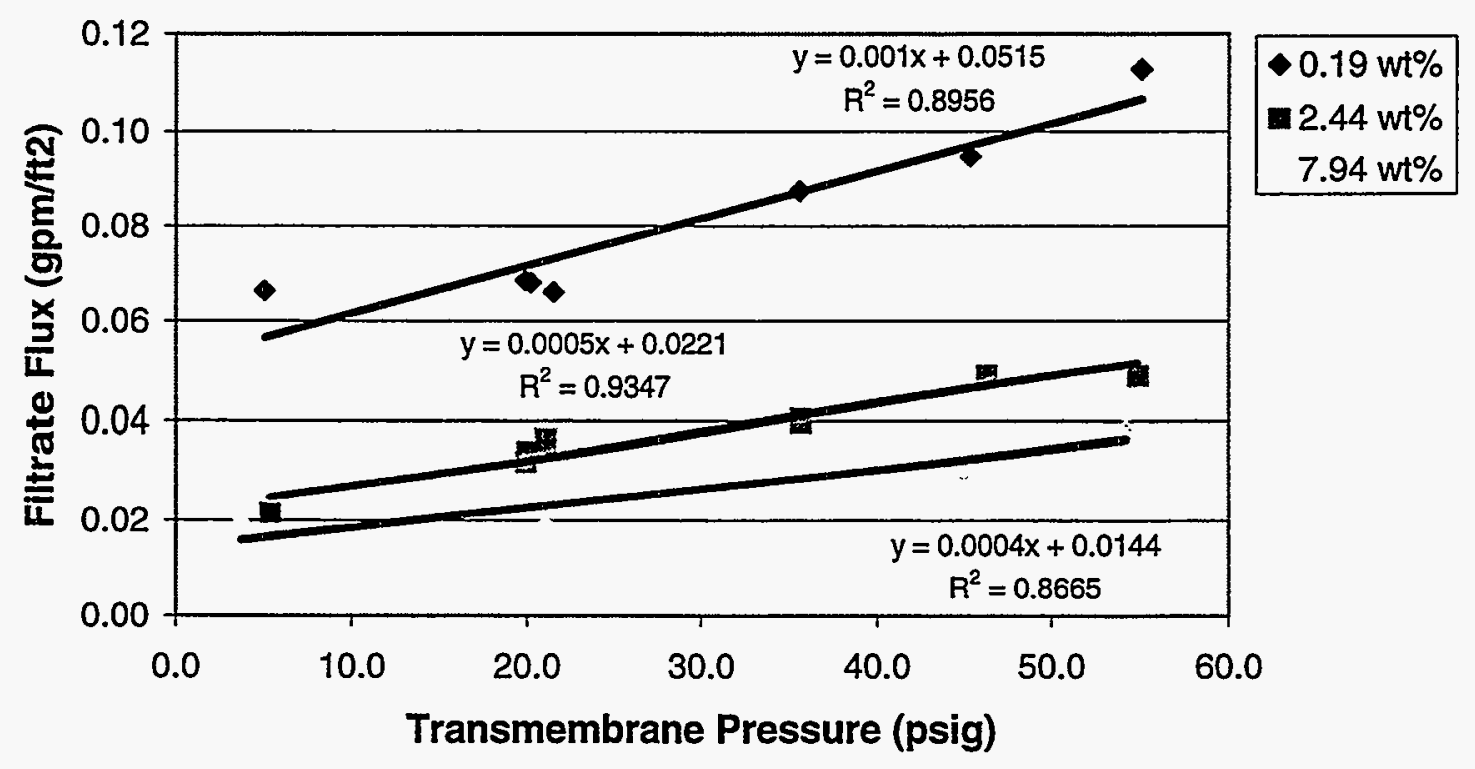

Figure 19. Filtrate flux as a function of transmembrane pressure for $0.19,2.44$ and 7.94 weight percent solids loading. 
Figure 20 displays filtrate flux as a function of axial velocity for $0.19,2.44$ and 7.94 weight percent solids loading, respectively. Decreases in slope and filtrate flux are observed with increased solids loading. Axial velocities are sufficient at removing filter cake, despite operating in Regime I. Additional increases in axial velocity will not increase filtrate flux. The operating system, at the highest solids loading, suggests the system is approaching Regime II.

Filtrate flux rates observed were substantially lower than expected. This decrease possibly suggests particles deeply embedded within the filter membrane. One theory proposed by Peterson and Nash (1995), that could possibly explain decreases in filtrate flow, describes the formation of a filter cake within the pores of the filter (and extending to barely cover the surface of the filter) (4). A similar phenomenon observed by Murkes and Carisson (1988) describes a decrease in flux due to internal plugging of the pores (7). Additional data displaying a substantial decrease in filtrate flow during baseline water run 2 confirm this theory. Shear deagglomeration is believed to be the main cause of filter fouling. Shear deagglomeration decreases particle size, which can induce internal plugging and/or lessen filter cake permeability. Moreover, if such a filter cake exists, increases in axial velocity would neither effect the cake and/or filtrate flux, since the filter cake would not be exposed to the bulk slurry.

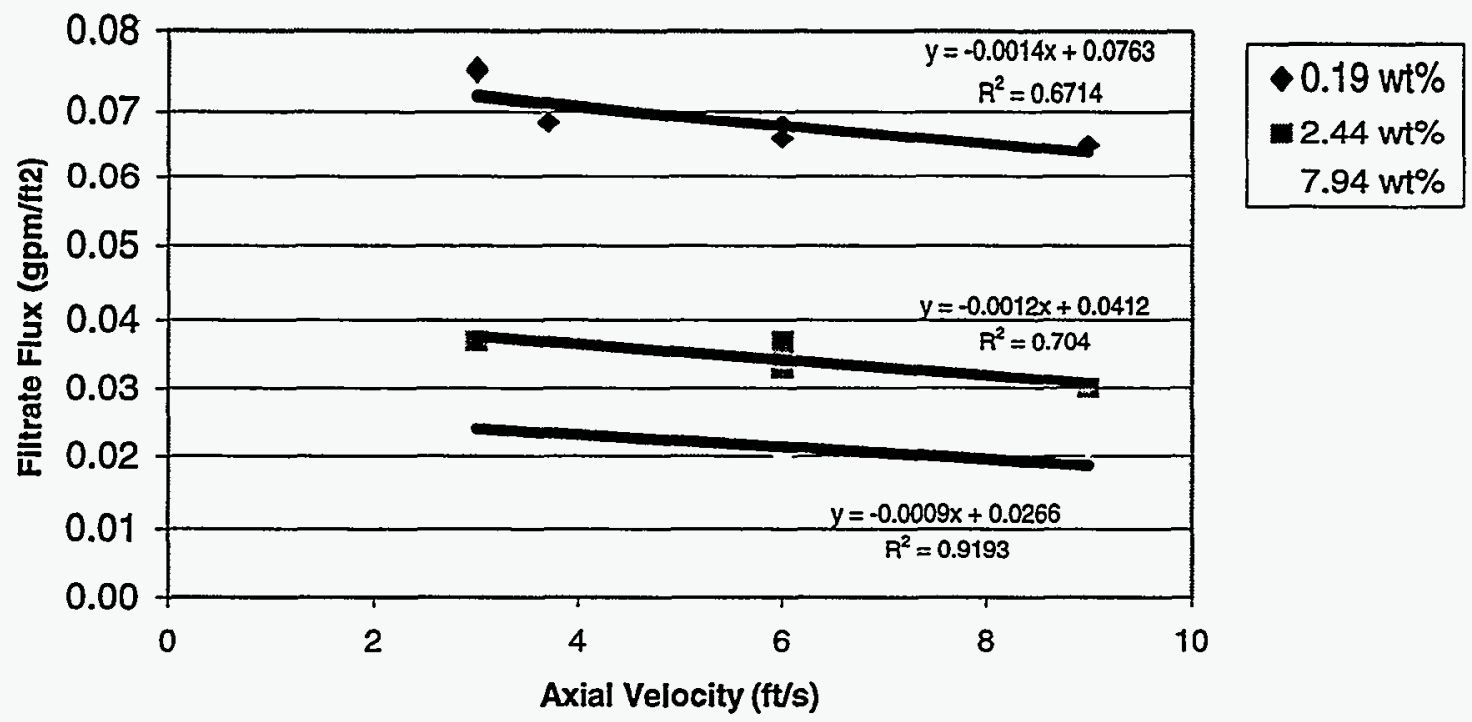

Figure 20. Filtrate flux as a function of axial velocity for $0.19,2.44$ and 7.94 weight percent solids loading. 


\section{FILTER EFFICIENCY}

Two, 200-mL effluent samples were collected to determination filter efficiency. Samples were taken by way of the V-6 filtrate-sampling valve. Filtrate samples were filtered through a Cole-Parmer $500 \mathrm{~mL}, 0.45$-micron filter unit and weighed. The remaining weight was used to determine filter efficiency. One sample was collected utilizing the dissolved $\mathrm{H}-4$ calcine containing 2.44 weight percent solids loading. The second $200-\mathrm{mL}$ sample was collected utilizing dissolved 1027 pilot plant calcine containing 7.94 weight percent solids loading. Each sample was obtained following two backpulses at the completion of condition 13. Filter efficiency calculations using the 2.44 and 7.94 weight percent solids loadings filtrate effluents are shown in Table 5.

Table 5. Filter efficiencies for 2.44 and 7.94 weight percent solids loading.

\begin{tabular}{lll}
\hline Sample & $\mathrm{H}-4(2.44 \mathrm{wt} \%)$ & $1027(7.94 \mathrm{wt} \%)$ \\
\hline $\begin{array}{l}\text { Tare wt. } \\
\text { (Filter Unit) }\end{array}$ & $68.160 \mathrm{~g}$ & $56.532 \mathrm{~g}$ \\
$\begin{array}{l}\text { Gross wt. } \\
\text { (UDS \& Filter Unit) }\end{array}$ & $68.214 \mathrm{~g}$ & $56.547 \mathrm{~g}$ \\
$\begin{array}{l}\text { Remaining UDS } \\
\begin{array}{l}\text { Reduction in } \\
\text { solids loading }\end{array}\end{array}$ & $0.054 \mathrm{~g}(0.00031 \mathrm{wt} \%)$ & $0.015 \mathrm{~g}(0.000094 \mathrm{wt} \%)$ \\
\hline
\end{tabular}

Previous studies have estimated that approximately 99.9 and $99.99 \%$ removal efficiency must be achieved In order to meet NRC Class A LLW requirements (8). Based on the results from this test, UDS reduction appears to meet the 99.9 and 99.99 removal efficiency.

Evaluation of the CUF apparatus utilizing feed slurries with increased solids loading was achieved by combining several batches of UDS. However, actual calcine feed solutions (excluding, stainless steel, dolomite and aluminum calcines) are expected to contain much lower solids loadings ( 0.15 to $0.25 w t \%)$. 


\section{BACKPULSE EFFICIENCY}

Backpulse efficiency can be determined by calculating the backpulse ratio (BP). The magnitude of the backpulse ratio is an indication of the effectiveness of the backpulse (4). High backpulse ratios suggest it is relatively easy to keep rejected particles from becoming part of the filter cake (and to transport the particles from the surface of the filter). Lower backpulse ratios suggest a faster development of filter cake (a result more indicative of the presence of a significant limitation to backtransport). The backpulse ratio is defined as:

\section{$\mathrm{BP}=$ Average filtrate flow for 20 minutes after backpulse Average steady state filtrate flow before backpulse}

The backpulse ratios for $0.19,2.44$ and 7.94 weight percent solids loadings are shown in Figure 21. Backpulse ratios for 0.19, 2.44 and 7.94 weight percent solids loading slurries are 1.5, 2.1 and 3.4, respectively. These data indicate a significant limitation to back-transport for the slurries with lower solids loadings. The $7.94 \mathrm{wt} \%$ solids slurry displays a higher backpulse ratio, suggesting back-transport of solids from the filter surface back into the feed stream.

Data suggest backpulsing efficiency increases with increased solids loading, indicating a transition from Regime I (pressure filtration resistance) to Regime II (mass transport resistance) with increased solids loading. It would appear that flowrates tested are efficient at removing filter cake from the filter media, assisting in backpulse efficiency. 


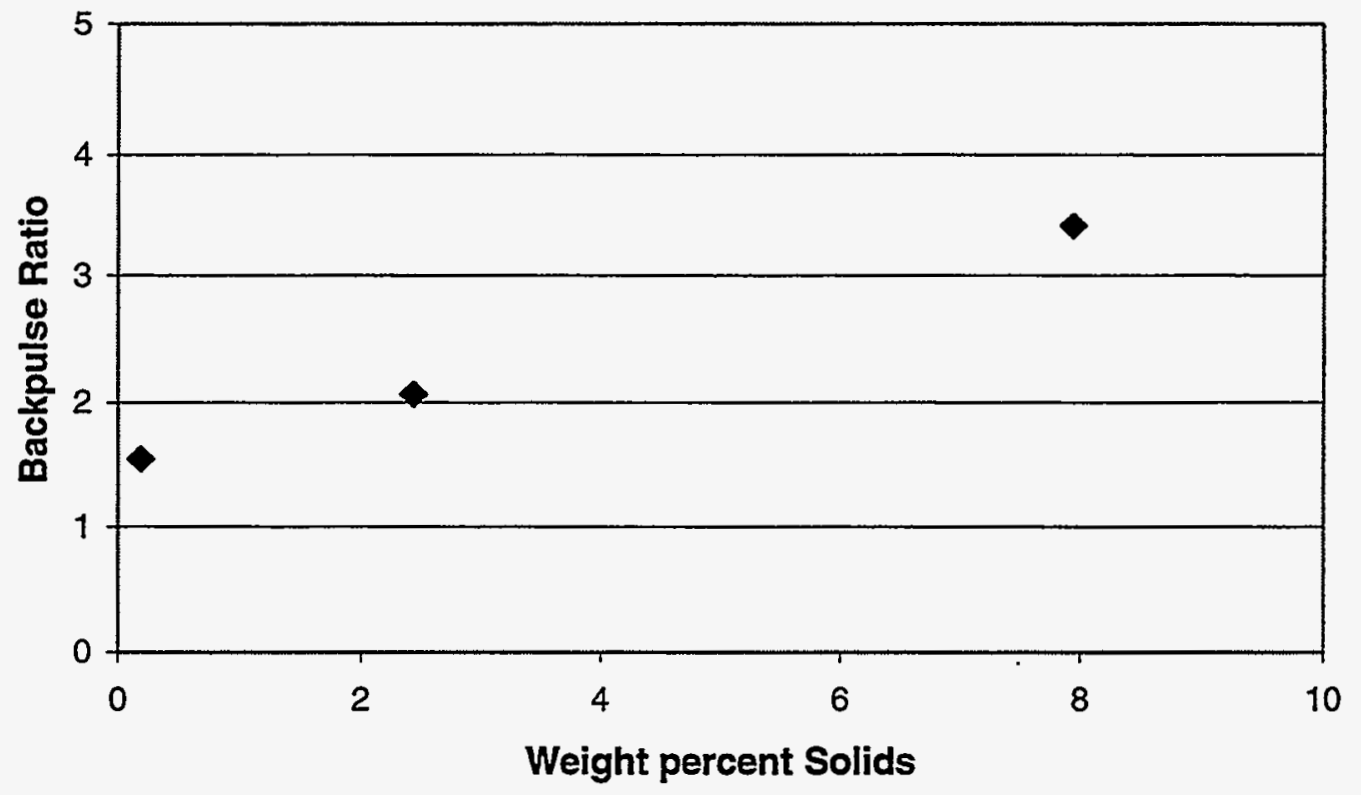

Figure 21. Backpulse ratios for $0.19,2.44$ and 7.94 weight percent solids loadings. 


\section{CONCLUSIONS}

The evaluation of cross flow filtration for the removal of UDS present in radioactive $\mathrm{H}-4$ dissolved calcine and non-radioactive Run 1027 dissolved calcine is presented in the following conclusions.

- Solids loading in radioactive $\mathrm{H}-4$ dissolved calcine was reduced from 2.44 weight percent to 0.00031 weight percent solids (99.987\%).

- Solids loading in non-radioactive Run 1027 pilot-plant dissolved calcine was reduced from 7.94 weight percent to 0.000094 weight percent solids (99.998\%).

- Filtrate flux rates for all solids loadings displayed high dependencies for transmembrane pressures indicating filtrate flux is controlled by Darcy's Equation. Moreover, filtrate flux rates for all solids loadings displayed negative dependencies for axial velocity, suggesting that all axial velocities tested were effective at removing filter cake

- Back pulsing proved to be beneficial at restoring filtrate flux, however, initial baseline filtrate flux rates were not achieved. Shear induced deagglomeration is believed to be the main cause of filter fouling.

- Backpulse efficiencies were determined by a ratio of average steady state filtrate flow immediately preceding a backpulse and the average filtrate flow for $\mathbf{3 0}$ minutes after backpulse. Backpulse ratios indicate limitations to backtransport for lower solids loadings, while higher solids loadings suggest a more efficient backtransport of solids from the filter back into the feed stream.

- Filtrate flux rates observed at time zero, displayed variations for recurrent conditions 1,6 and 11. This would indicate backpulse procedures performed during testing were inconsistant. 
- Cross flow filtration was effective at filtering $0.19,2.44$ and 7.94 weight percent solids loading and is a viable method for the removal of UDS from INEEL dissolved calcine slurries. 


\section{RECOMMENDATIONS}

Based on the results from this study, the following recommendations are made.

- Evaluate chemical filter cleaning techniques to reduce the amount of filter fouling without dissolving the filter media. Moreover, evaluate the effect of smaller pore size filters on internal plugging.

- Evaluate more consistent backpulsing procedures.

- Evaluate the corrosive properties of baseline and alternative filter media.

- Analyze and characterize UDS for other INEEL dissolved calcine slurries.

- Fabricate and test a bench-scale cross flow filtration apparatus on pilot plant calcine slurries. 


\section{REFERENCES}

1. Tripp, J. L., Wade, E. L., "FY-97 Experimental Results Of the Cells Unit Crossflow Filter Tests at the INEEL", INEEL/EXT-97-01232, November 1997.

2. U.S. Department of Energy, Office of Science and Technology., Innovative Technology Summary Report \#350, "Crossflow Filtration" February 98.

3. Geeting, J. G. H., Reynolds, B. A., "Bench-Scale Crossflow Filtration of Tank S-107 Sludge Slurries and Tank C-107 Supernatant", PNNL-11376 (UC-721), October 1996.

4. Peterson, R. A., Nash, C. A., "Filter Performance Mechanisms (U)", WSRC-TR-950420, October 20, 1995.

5. Herbst, R. S., Fryer, D. S., Brewer, K. N., Johnson, C. K., Todd, T. A., "Experimental Results: Pilot Plant Calcine Dissolution and Liquid Feed Stability", INEL-95/0097, February 1995.

6. Brose, D., Dosmar, M., Cates, S., Hutchison, F., "Studies on the Scale-Up of Crossflow Filtration Devices", PDA Journal of Pharmaceutical Science and Technology, Vol.50, No. 4, July-August 1996.

7. Murkes, J., Carlsson C. G., "Crossflow Filtration", John Wiley and Sons, New York, NY,1988.

8. Brewer, K. N., Herbst, R. S., Tranter, T. J., Olson, A. L., Todd, T. A., Goodwin, I. D., Lundholm, C. W., "Dissolution of Two NWCF Calcines: Extent of Dissolution and Characterization of Undissolved Solids", INEL-95/0098, February 1995. 
APPENDIX:

EXPERIMENTAL DATA 
Dissolved H-4 Calcine (0.19 wt \%)

CONDMON (1) 6ft's axial velocity (3.7 gpm in flowmeter) $20.0 \mathrm{psig}$ transmembrane pressure

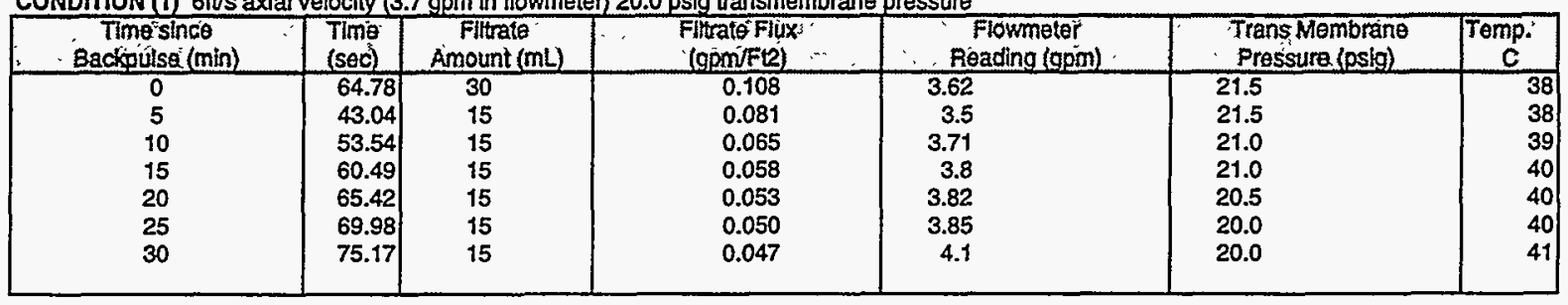

CONDMON (2) $7.5 \mathrm{fts}$ axial velocity (4.6 gpm in flowmeter) $27.5 \mathrm{psig}$ transmembrane pressure

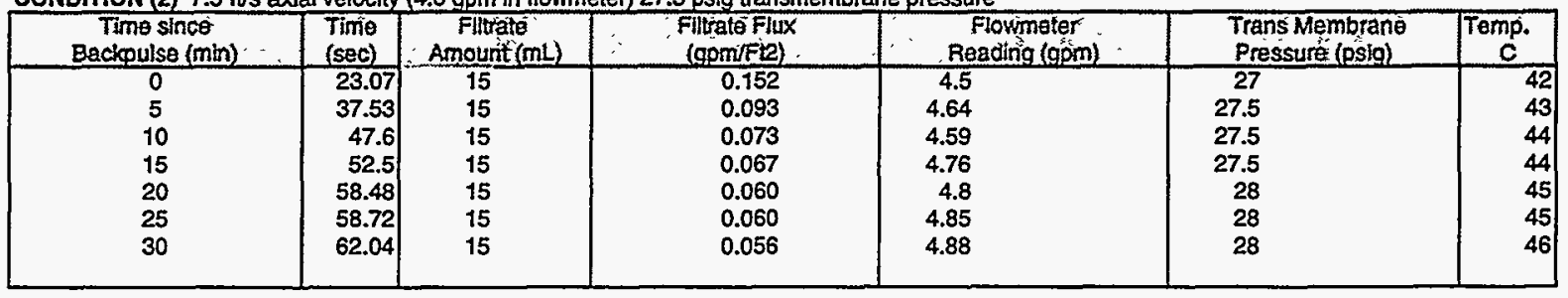

CONDITON (3) $3.0 \mathrm{ft} / \mathrm{s}$ axial velocity (1.8 gpm in flowmeter) $20.0 \mathrm{psig}$ transmembrane pressure

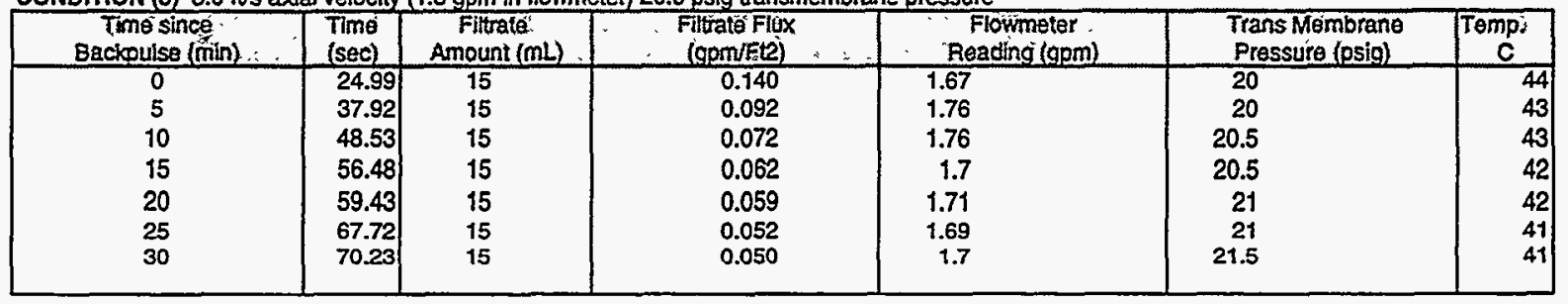

CONDITION (4) $6.0 \mathrm{ft} / \mathrm{s}$ axial velocity (3.7 gpm in flowmeter) $5.0 \mathrm{psig}$ transmembrane pressure

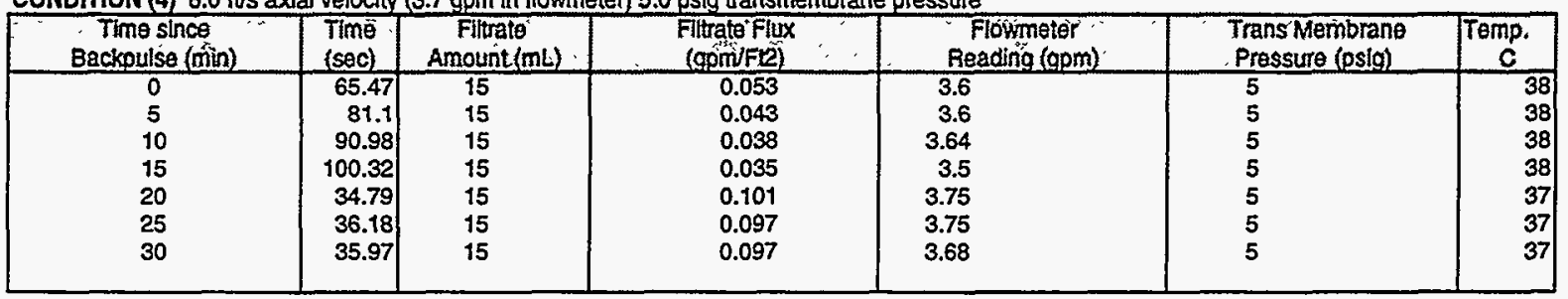

CONDITON (5) $7.5 \mathrm{ft}$ /s axial velocity (4.6 gpm in flowmeter) $12.5 \mathrm{psig}$ transmembrane pressure

\begin{tabular}{|c|c|c|c|c|c|c|}
\hline $\begin{array}{l}\text { Time since } \\
\text { Backpulsé(min) }\end{array}$ & $\begin{array}{l}\operatorname{Time} \\
\text { (sec) }\end{array}$ & $\begin{array}{c}\text { Filtrate } \\
\text { Amount }(\mathrm{mL})\end{array}$ & $\begin{array}{l}\text { Filtrate Flux } \\
\text { (gom/F(2) }\end{array}$ & $\begin{array}{l}\text { Flowneter } \\
\text { Reading (opm) }\end{array}$ & $\begin{array}{l}\text { Transinembrano } \\
\text { Pressure (psig) }\end{array}$ & $\begin{array}{c}\text { Temp. } \\
\text { C }\end{array}$ \\
\hline $\begin{array}{l}0 \\
5\end{array}$ & $\begin{array}{r}26.6 \\
54.73\end{array}$ & $\begin{array}{l}15 \\
15\end{array}$ & 0.131 & 4.6 & 12.5 & 38 \\
\hline 10 & 60.78 & $\begin{array}{l}10 \\
15\end{array}$ & $\begin{array}{l}0.064 \\
0.058\end{array}$ & $\begin{array}{l}4.55 \\
4.55\end{array}$ & $\begin{array}{l}72.5 \\
12.5\end{array}$ & 38 \\
\hline 15 & 72.97 & 15 & 0.048 & 4.58 & 13 & 38 \\
\hline 20 & 76.78 & 15 & 0.046 & 4.5 & 12.5 & 38 \\
\hline 25 & 82.17 & 15 & 0.043 & 4.56 & 13 & 39 \\
\hline 30 & 80.78 & 15 & 0.043 & 4.6 & 13 & 39 \\
\hline
\end{tabular}

CONDMON (6) $6 \mathrm{ft} / \mathrm{s}$ axial velocity (3.7 gpm in flowmeter) $20.0 \mathrm{psig}$ transmembrane pressure

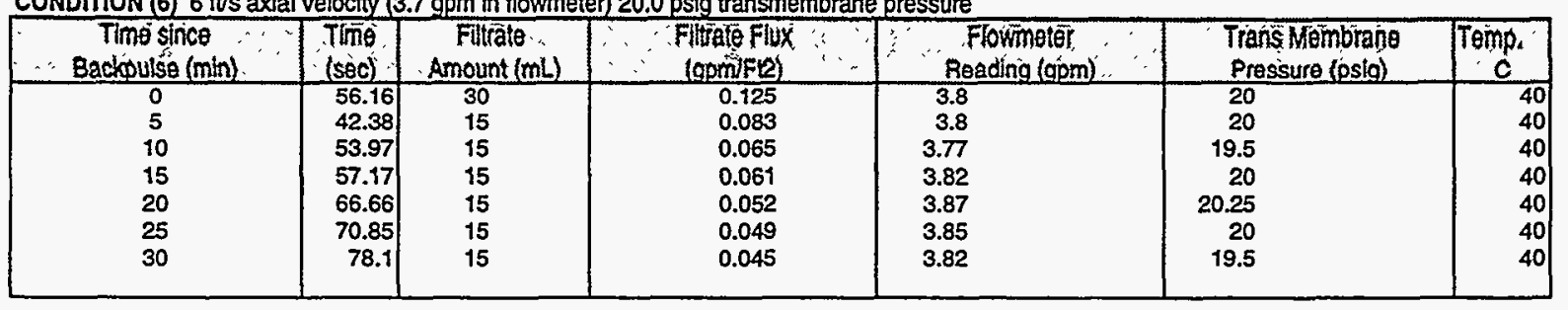


CONDITION (7) $4.5 \mathrm{ft} / \mathrm{s}$ axial velocity (2.8 gpm in flowmeter) $27.5 \mathrm{psig}$ transmembrane pressure

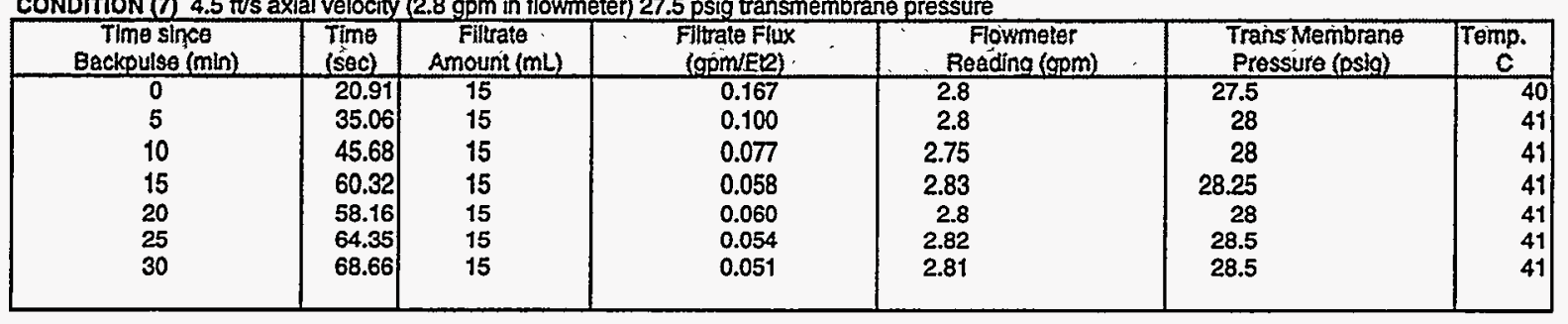

CONDITION (8) $6 \mathrm{ft} / \mathrm{s}$ axial velocity ( $3.7 \mathrm{gpm}$ in flowmeter) $35 \mathrm{psig}$ transmembrane pressure

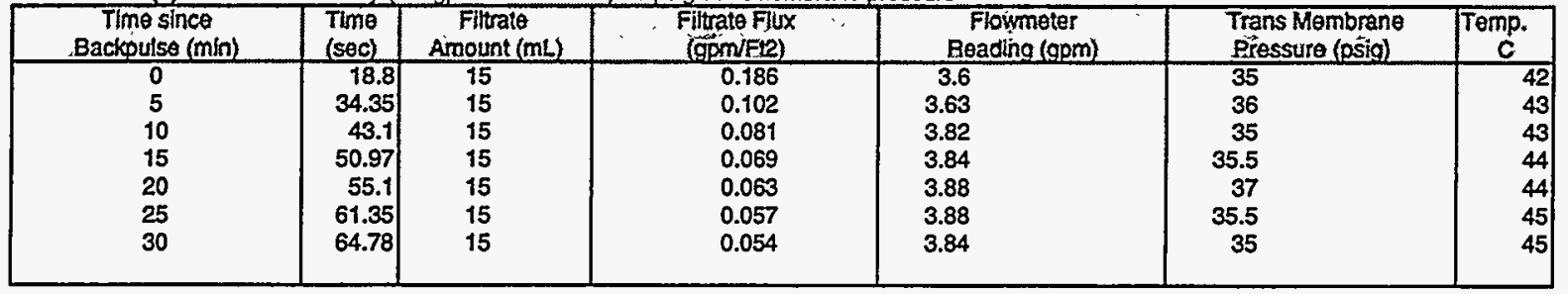

CONDITION (9) $4.5 \mathrm{ft} / \mathrm{s}$ axial velocity (2.8 gpm in flowmeter) $12.5 \mathrm{psig}$ transmembrane pressure

\begin{tabular}{|c|c|c|c|c|c|c|}
\hline $\begin{array}{c}\text { Timo since } \\
\text { Backpulse'(min) }\end{array}$ & $\begin{array}{l}\text { Time } \\
\text { (séc) }\end{array}$ & $\begin{array}{l}\text { Filtrate } \\
\text { Amount }(\mathrm{mL})\end{array}$ & $\begin{array}{l}\text { Flitrate Flux } \\
\text { (gpm/Ft2) }\end{array}$ & $\begin{array}{c}\text { Flowmeter } \\
\text { Reading (gjm) }\end{array}$ & $\begin{array}{l}\text { Trans Membrans } \\
\text { Pressure (psia) }\end{array}$ & Temp. \\
\hline $\begin{array}{c}0 \\
5 \\
10 \\
15 \\
20 \\
25 \\
30\end{array}$ & \begin{tabular}{r|}
36.54 \\
50.85 \\
58.18 \\
66.9 \\
78.28 \\
84.67 \\
87.72
\end{tabular} & $\begin{array}{l}15 \\
15 \\
15 \\
15 \\
15 \\
15 \\
15\end{array}$ & $\begin{array}{l}0.096 \\
0.069 \\
0.060 \\
0.052 \\
0.045 \\
0.041 \\
0.040\end{array}$ & $\begin{array}{r}2.6 \\
2.8 \\
2.76 \\
2.63 \\
2.7 \\
2.69 \\
2.7\end{array}$ & $\begin{array}{r}12 \\
12.75 \\
13 \\
13.5 \\
12.5 \\
12 \\
12.5\end{array}$ & $\begin{array}{l}38 \\
38 \\
38 \\
37 \\
37 \\
37 \\
37\end{array}$ \\
\hline
\end{tabular}

CONDITION (10) $9 \mathrm{ft} / \mathrm{s}$ axial velocity (5.5 gpm in flowmeter) $20.0 \mathrm{psig}$ transmembrane pressure

\begin{tabular}{|c|c|c|c|c|c|c|}
\hline $\begin{array}{c}\text { Timesince } \\
\text { Backpulse.(min) }\end{array}$ & $\begin{array}{l}\operatorname{Tim} \theta \\
\text { (sec) }\end{array}$ & $\begin{array}{l}\text { Eilfiale } \\
\text { Amóunt (mL) }\end{array}$ & $\begin{array}{l}\text { Fltuate Flux } \\
\text { (gominte) }\end{array}$ & $\begin{array}{c}\text { Flowmeler } \\
\text { Beading lopm) }\end{array}$ & $\begin{array}{l}\text { Trans Membrane } \\
\text { Pressure (psig) }\end{array}$ & $\begin{array}{c}\text { Temp. } \\
\mathrm{C}\end{array}$ \\
\hline $\begin{array}{c}0 \\
5 \\
10 \\
15 \\
20 \\
25 \\
30\end{array}$ & $\begin{array}{l}28.81 \\
46.88 \\
56.68 \\
64.73 \\
68.49 \\
75.98 \\
51.66\end{array}$ & $\begin{array}{l}15 \\
15 \\
15 \\
15 \\
15 \\
15 \\
10\end{array}$ & $\begin{array}{l}0.121 \\
0.075 \\
0.062 \\
0.054 \\
0.051 \\
0.046 \\
0.045\end{array}$ & $\begin{array}{r}5.53 \\
5.55 \\
5.62 \\
5.6 \\
5.8 \\
5.63 \\
5.67\end{array}$ & $\begin{array}{r}20 \\
19.5 \\
20 \\
20.25 \\
21 \\
20 \\
20.5\end{array}$ & $\begin{array}{l}38 \\
39 \\
39 \\
40 \\
40 \\
40 \\
41\end{array}$ \\
\hline
\end{tabular}

\begin{tabular}{|c|c|c|c|c|c|c|}
\hline $\begin{array}{c}\text { Time since } \\
\text { Backpulse (min) }\end{array}$ & $\begin{array}{l}\text { Time } \\
\text { (sec) }\end{array}$ & $\begin{array}{c}\text { Filtrate } \\
\text { Amount }(\mathrm{mL})\end{array}$ & $\begin{array}{l}\text { Filbate Flux } \\
\text { (gom/ER) }\end{array}$ & $\begin{array}{c}\text { Flowmeter } \\
\text { Reading (opm) }\end{array}$ & $\begin{array}{l}\text { Trans Membrane } \\
\text { Pressure (psig) }\end{array}$ & {$\left[\begin{array}{c}\text { Temp. } \\
6\end{array}\right.$} \\
\hline $\begin{array}{c}0 \\
5 \\
10 \\
15 \\
20 \\
25 \\
30\end{array}$ & \begin{tabular}{|r|r}
26.55 \\
41.6 \\
52.48 \\
63.91 \\
68.47 \\
81.92 \\
76.6
\end{tabular} & $\begin{array}{l}15 \\
15 \\
15 \\
15 \\
15 \\
15 \\
15\end{array}$ & $\begin{array}{l}0.132 \\
0.084 \\
0.067 \\
0.055 \\
0.051 \\
0.043 \\
0.046\end{array}$ & $\begin{array}{r}3.71 \\
3.65 \\
3.6 \\
3.49 \\
3.9 \\
3.4 \\
3.7\end{array}$ & $\begin{array}{r}20 \\
20 \\
20.5 \\
20 \\
21.5 \\
18.5 \\
21\end{array}$ & \begin{tabular}{|l|}
40 \\
40 \\
40 \\
40 \\
40 \\
40 \\
40
\end{tabular} \\
\hline
\end{tabular}

\begin{tabular}{|c|c|c|c|c|c|c|}
\hline $\begin{array}{c}\text { Time since } \\
\text { Backpulse:(min) }\end{array}$ & $\begin{array}{l}\text { Time } \\
(\mathrm{sec})\end{array}$ & $\begin{array}{c}\text { Filtrate } \\
\text { Amounin }(\mathrm{mL})\end{array}$ & $\begin{array}{l}\text { Filtrate Flux } \\
\text { (opin/Ft) }\end{array}$ & $\begin{array}{l}\text { Flowmetor } \\
\text { Reading (gom) }\end{array}$ & $\begin{array}{l}\text { Trans Membrane } \\
\text { Pressure.psig) }\end{array}$ & $\begin{array}{r}\text { Temp. } \\
0\end{array}$ \\
\hline $\begin{array}{c}0 \\
5 \\
10 \\
15 \\
20 \\
25 \\
30\end{array}$ & \begin{tabular}{r|}
32.56 \\
32.1 \\
42.17 \\
48.91 \\
52.61 \\
56.11 \\
61.67
\end{tabular} & $\begin{array}{l}30 \\
15 \\
15 \\
15 \\
15 \\
15 \\
15\end{array}$ & $\begin{array}{l}0.215 \\
0.109 \\
0.083 \\
0.071 \\
0.066 \\
0.062 \\
0.057\end{array}$ & $\begin{array}{r}3.75 \\
3.65 \\
3.7 \\
3.75 \\
3.68 \\
3.74 \\
3.7\end{array}$ & $\begin{array}{r}45 \\
46 \\
46 \\
46 \\
46 \\
45 \\
43.5\end{array}$ & $\begin{array}{l}\text { N/A } \\
\text { N/A } \\
\text { N/A } \\
\text { N/A } \\
\text { N/A } \\
\text { N/A } \\
\text { N/A }\end{array}$ \\
\hline
\end{tabular}


CONDITION (13) $6 \mathrm{ft} / \mathrm{s}$ axial velocity $(3.7 \mathrm{gpm}$ in flowmeter) $55.0 \mathrm{psig}$ transmembrane pressure

\begin{tabular}{|c|c|c|c|c|c|c|}
\hline $\begin{array}{c}\text { Time since } \\
\text { Backpulse (min) }\end{array}$ & $\begin{array}{l}\text { Time } \\
\text { (sec) }\end{array}$ & $\begin{array}{c}\text { Fittrate } \\
\text { Amount (mL) }\end{array}$ & $\begin{array}{l}\text { Filltate Fiux } \\
\text { (gom/Ft2) }(0.068)\end{array}$ & $\begin{array}{c}\text { Foumbtar } \\
\text { Reaúding (gom) }\end{array}$ & $\begin{array}{l}\text { Trans Membran } \\
\text { Pressure (psig) }\end{array}$ & $\begin{array}{c}\text { Temp. } \\
\mathrm{c}\end{array}$ \\
\hline 0 & 28.94 & 30 & 0.242 & 3.68 & 55 & 48 \\
\hline 5 & 28.97 & 15 & 0.121 & 3.69 & 55 & 49 \\
\hline 10 & 36.23 & 15 & 0.097 & 3.7 & 55 & 50 \\
\hline 15 & 41.91 & 15 & 0.083 & 3.68 & 55 & 51 \\
\hline 20 & 31.04 & 15 & 0.113 & 3.71 & 55 & 51 \\
\hline 25 & 50.53 & 15 & 0.069 & 3.69 & 55.5 & 52 \\
\hline 30 & 53.6 & 15 & 0.065 & 3.75 & 55 & 52 \\
\hline
\end{tabular}


Dissolved H-4 Calcine (2.44 wt \%)

CONDITION (1) $6 \mathrm{ft} / \mathrm{s}$ axial velocity ( $3.7 \mathrm{gpm}$ in flowmeter) $20.0 \mathrm{psig}$ transmembrane pressure

\begin{tabular}{|c|c|c|c|c|c|c|}
\hline $\begin{array}{c}\text { Time since } \\
\text { Backpulse (mín) }\end{array}$ & $\begin{array}{l}\operatorname{Tim} \theta \\
(s \in c)\end{array}$ & $\begin{array}{l}\text { Filtrato } \\
\text { Amount }(\mathrm{mL})\end{array}$ & $\begin{array}{l}\text { Filtrate Flux } \\
\text { (gpin/Fte) }\end{array}$ & $\begin{array}{l}\text { Flowmeter } \\
\text { Reading (gpm) }\end{array}$ & $\begin{array}{l}\text { Trans Membrane } \\
\text { Pressure (psig) }\end{array}$ & $\begin{array}{c}\text { Temp. } \\
\mathrm{c}\end{array}$ \\
\hline $\begin{array}{c}0 \\
5 \\
10 \\
15 \\
20 \\
25 \\
30\end{array}$ & $\begin{array}{l}38.8 \\
93.1 \\
82.1 \\
47.7 \\
55.5 \\
60.2 \\
62.2\end{array}$ & $\begin{array}{r}15 \\
15 \\
10 \\
5 \\
5 \\
5 \\
5\end{array}$ & $\begin{array}{l}0.090 \\
0.038 \\
0.028 \\
0.024 \\
0.021 \\
0.019 \\
0.019\end{array}$ & $\begin{array}{l}3.6 \\
3.7 \\
3.6 \\
3.6 \\
3.6 \\
3.6 \\
3.6\end{array}$ & $\begin{array}{l}20.5 \\
20.0 \\
20.0 \\
20.0 \\
20.0 \\
19.5 \\
20.0\end{array}$ & $\begin{array}{l}\text { N/A } \\
\text { N/A } \\
\text { N/A } \\
\text { N/A } \\
\text { N/A } \\
\text { N/A } \\
\text { N/A }\end{array}$ \\
\hline
\end{tabular}

CONDIIION (2) $7.5 \mathrm{ft} / \mathrm{s}$ axial velocity (4.6 gpm in flowmeter) $27.5 \mathrm{psig}$ transmembrane pressure

\begin{tabular}{|c|c|c|c|c|c|c|}
\hline $\begin{array}{c}\text { Timesince } \\
\text { Backpulse (min) }\end{array}$ & $\begin{array}{l}\text { Time } \\
(\mathrm{sec})\end{array}$ & $\begin{array}{c}\text { Fiftrate } \\
\text { Amount (mL) }\end{array}$ & $\begin{array}{l}\text { Fitrate Filex } \\
\text { (gpm/Ft) }\end{array}$ & $\begin{array}{l}\text { Flowmoter } \\
\text { Reading (gam) }\end{array}$ & $\begin{array}{l}\text { Trans Membrano } \\
\text { Pressure (psig) }\end{array}$ & Temp. \\
\hline $\begin{array}{c}0 \\
5 \\
10 \\
15 \\
20 \\
25 \\
30\end{array}$ & $\begin{array}{l}22.4 \\
28.0 \\
35.0 \\
48.5 \\
51.4 \\
53.4 \\
55.8\end{array}$ & $\begin{array}{r}10 \\
5 \\
5 \\
5 \\
5 \\
5 \\
5\end{array}$ & $\begin{array}{l}0.104 \\
0.042 \\
0.033 \\
0.024 \\
0.023 \\
0.022 \\
0.021\end{array}$ & $\begin{array}{l}4.6 \\
4.4 \\
4.5 \\
4.7 \\
4.7 \\
4.6 \\
4.8\end{array}$ & $\begin{array}{l}28.5 \\
27.5 \\
28.0 \\
28.0 \\
27.5 \\
27.0 \\
27.0\end{array}$ & $\begin{array}{l}\text { N/A } \\
\text { N/A } \\
\text { N/A } \\
\text { N/A } \\
\text { N/A } \\
\text { N/A } \\
\text { N/A }\end{array}$ \\
\hline
\end{tabular}

CONDMON (3) $3.0 \mathrm{ft} / \mathrm{s}$ axial velocity (1.8 gpm in flowmeter) $20.0 \mathrm{psig}$ transmembrane pressure

\begin{tabular}{|c|c|c|c|c|c|c|}
\hline $\begin{array}{c}\text { Timesince } \\
\text { Backpuise (min) }\end{array}$ & $\begin{array}{l}\text { Time } \\
\text { (sec) }\end{array}$ & $\begin{array}{c}\text { Filuate } \\
\text { Amount (mL) }\end{array}$ & $\begin{array}{c}\because \text { Fitrate Flux } \\
\text { (opminte) }\end{array}$ & $\begin{array}{c}\text { Flowmeler } \\
\text { Reading (gpm) }\end{array}$ & $\begin{array}{l}\text { Trans Membrane } \\
\text { Eressure (psia) }\end{array}$ & $\begin{array}{c}\text { Temp. } \\
\mathrm{c}\end{array}$ \\
\hline $\begin{array}{c}0 \\
5 \\
10 \\
15 \\
20 \\
25 \\
30\end{array}$ & $\begin{array}{l}20.7 \\
30.4 \\
39.1 \\
51.7 \\
57.0 \\
60.2 \\
67.1\end{array}$ & $\begin{array}{r}10 \\
5 \\
5 \\
5 \\
5 \\
5 \\
5\end{array}$ & $\begin{array}{l}0.113 \\
0.038 \\
0.030 \\
0.023 \\
0.020 \\
0.019 \\
0.017\end{array}$ & $\begin{array}{l}1.8 \\
1.8 \\
1.8 \\
1.8 \\
1.8 \\
1.8 \\
1.8\end{array}$ & $\begin{array}{l}20.0 \\
19.5 \\
20.0 \\
20.0 \\
20.0 \\
20.5 \\
20.5\end{array}$ & $\begin{array}{l}\text { N/A } \\
\text { N/A } \\
\text { N/A } \\
\text { N/A } \\
\text { N/A } \\
\text { N/A } \\
\text { N/A }\end{array}$ \\
\hline
\end{tabular}

CONDITION (4) $6.0 \mathrm{ft} / \mathrm{s}$ axial velocity $(3.7 \mathrm{gpm}$ in flowmeter) $5.0 \mathrm{psig}$ transmembrane pressure

\begin{tabular}{|c|c|c|c|c|c|c|}
\hline $\begin{array}{c}\text { Timo since } \\
\text { Backpulse (min) }\end{array}$ & $\begin{array}{l}\text { Time } \\
(\mathrm{sec})\end{array}$ & $\begin{array}{c}\text { Filtrate } \\
\text { Amount }(\mathrm{mL})\end{array}$ & $\begin{array}{l}\text { Filfrate Flux } \\
\text { (gpm/Eis) }\end{array}$ & $\begin{array}{c}\text { Flowmater } \\
\text { Reading (gom) }\end{array}$ & $\begin{array}{l}\text { Trans Membrane } \\
\text { Pressure (psig) }\end{array}$ & Temp. \\
\hline $\begin{array}{c}0 \\
5 \\
10 \\
15 \\
20 \\
25 \\
30\end{array}$ & $\begin{array}{l}46.0 \\
44.2 \\
50.7 \\
59.0 \\
71.3 \\
76.2 \\
77.2\end{array}$ & $\begin{array}{l}7 \\
5 \\
5 \\
5 \\
5 \\
5 \\
5\end{array}$ & $\begin{array}{l}0.035 \\
0.026 \\
0.023 \\
0.020 \\
0.016 \\
0.015 \\
0.015\end{array}$ & $\begin{array}{l}3.6 \\
3.5 \\
3.7 \\
3.7 \\
3.7 \\
3.7 \\
3.8\end{array}$ & $\begin{array}{l}5.0 \\
5.0 \\
5.3 \\
5.5 \\
5.5 \\
5.5 \\
5.5\end{array}$ & $\begin{array}{l}\text { N/A } \\
\text { N/A } \\
\text { N/A } \\
\text { N/A } \\
\text { N/A } \\
\text { N/A } \\
\text { N/A }\end{array}$ \\
\hline
\end{tabular}

CONDITION (5) $7.5 \mathrm{ft} / \mathrm{s}$ axial velocity (4.6 gpm in flowmeter) $12.5 \mathrm{psig}$ transmembrane pressure

\begin{tabular}{|c|c|c|c|c|c|c|}
\hline $\begin{array}{c}\text { Time since } \\
\text { Backpulse (min) }\end{array}$ & $\begin{array}{l}\operatorname{Tim} \theta \\
(\mathrm{sec})\end{array}$ & $\begin{array}{l}\text { Filtrate } \\
\text { Amount (mL) }\end{array}$ & $\begin{array}{l}\text { Filtrate Flux } \\
\text { (gom/st2) }\end{array}$ & $\begin{array}{c}\text { Flowmeter } \\
\text { Reading (gpm) }\end{array}$ & $\begin{array}{l}\text { Trans Membraine } \\
\text { Pressure (psig) }\end{array}$ & Tomp. \\
\hline $\begin{array}{c}0 \\
5 \\
10 \\
15 \\
20 \\
25 \\
30\end{array}$ & \begin{tabular}{r|}
48.6 \\
102.9 \\
44.2 \\
53.1 \\
58.0 \\
62.0 \\
66.4
\end{tabular} & $\begin{array}{r}15 \\
15 \\
5 \\
5 \\
5 \\
5 \\
5\end{array}$ & $\begin{array}{l}0.072 \\
0.034 \\
0.026 \\
0.022 \\
0.020 \\
0.019 \\
0.018\end{array}$ & $\begin{array}{l}4.8 \\
4.8 \\
4.5 \\
4.6 \\
4.7 \\
4.6 \\
4.6\end{array}$ & $\begin{array}{l}13.5 \\
13.5 \\
12.5 \\
12.5 \\
12.5 \\
12.5 \\
12.5\end{array}$ & $\begin{array}{l}\text { N/A } \\
\text { N/A } \\
\text { N/A } \\
\text { N/A } \\
\text { N/A } \\
\text { N/A } \\
\text { N/A }\end{array}$ \\
\hline
\end{tabular}

\begin{tabular}{|c|c|c|c|c|c|c|}
\hline $\begin{array}{c}\text { Time since } \\
\text { Backpuise (min) }\end{array}$ & $\begin{array}{r}\text { Timo } \\
\text { (sec) } \\
\end{array}$ & $\begin{array}{l}\text { Fitrato } \\
\text { Amount (mL) }\end{array}$ & $\begin{array}{l}\text { Flltate Fiux } \\
\text { (gpim/Ri2) }\end{array}$ & $\begin{array}{l}\text { Flowmeter } \\
\text { Reading (Gpm) }\end{array}$ & $\begin{array}{l}\text { Trans Membrane } \\
\text { Pressure (psig) }\end{array}$ & $\begin{array}{c}\text { Temp. } \\
\mathrm{c}\end{array}$ \\
\hline $\begin{array}{c}0 \\
5 \\
10 \\
15 \\
20 \\
25 \\
30\end{array}$ & $\begin{array}{l}35.5 \\
31.2 \\
37.6 \\
45.4 \\
49.6 \\
58.0 \\
58.1\end{array}$ & $\begin{array}{r}15 \\
5 \\
5 \\
5 \\
5 \\
5 \\
5\end{array}$ & $\begin{array}{l}0.098 \\
0.037 \\
0.031 \\
0.026 \\
0.024 \\
0.020 \\
0.020\end{array}$ & $\begin{array}{l}3.7 \\
3.7 \\
3.7 \\
3.8 \\
3.7 \\
3.7 \\
3.7\end{array}$ & $\begin{array}{l}20.3 \\
21.5 \\
21.0 \\
21.0 \\
21.0 \\
21.5 \\
21.0\end{array}$ & $\begin{array}{l}\text { N/A } \\
\text { N/A } \\
\text { N/A } \\
\text { N/A } \\
\text { N/A } \\
\text { N/A } \\
\text { N/A }\end{array}$ \\
\hline
\end{tabular}


CONDITION (7) $4.5 \mathrm{ft} / \mathrm{s}$ axial velocity (2.8 gpm in flowmeter) $27.5 \mathrm{psig}$ transmembrane pressure

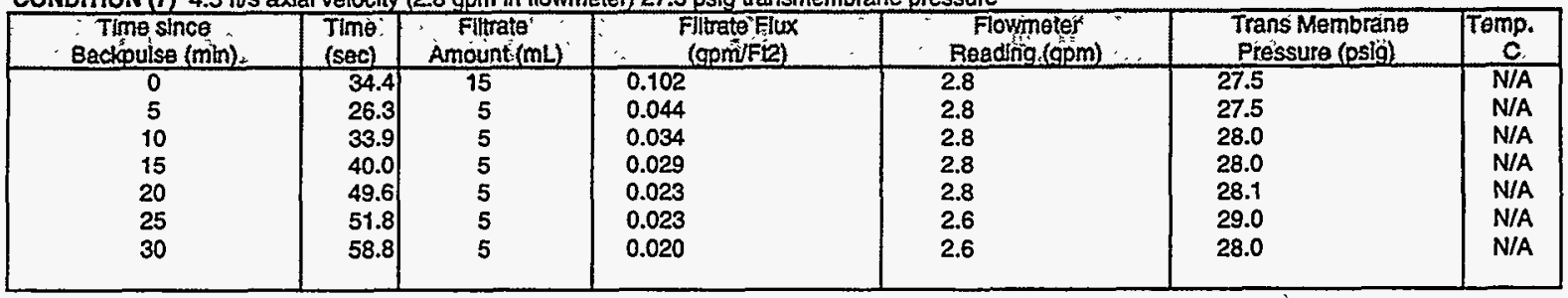

CONDITION (8) $6 \mathrm{ft} / \mathrm{s}$ axial velocity (3.7 gpm in flowmeter) $35 \mathrm{psig}$ transmembrane pressure

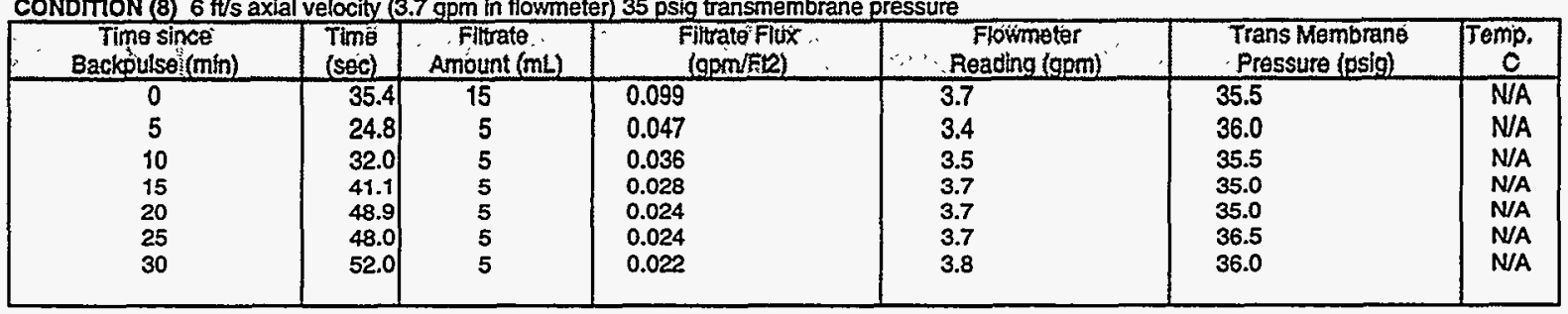

CONDITON (9) $4.5 \mathrm{ft} / \mathrm{s}$ axial velocity (2.8 gpm in flowmeter) $12.5 \mathrm{psig}$ transmembrane pressure

\begin{tabular}{|c|c|c|c|c|c|c|}
\hline $\begin{array}{c}\text { Timo since } \\
\text { Beckpulse (min) }\end{array}$ & $\begin{array}{l}\text { Time } \\
\text { (sec) }\end{array}$ & $\begin{array}{c}\text { Filtrate } \\
\text { Amount (mL) }\end{array}$ & $\begin{array}{l}\text { Filtoté Flux } \\
\text { (cpomif(2) }\end{array}$ & $\begin{array}{c}\text { Flowmeter } \\
\text { Heading (opm) }\end{array}$ & $\begin{array}{l}\text { Trans Membraino } \\
\text { Pressure (psig) }\end{array}$ & Temp. ${ }^{13}$ \\
\hline 0 & 64.0 & 15 & 0.055 & 2.7 & 13.0 & N/A \\
\hline 5 & 34.5 & 5 & 0.034 & 2.8 & 13.0 & N/A \\
\hline 10 & 40.9 & 5 & 0.028 & 2.9 & 13.0 & N/A \\
\hline 15 & 52.2 & 5 & 0.022 & 2.8 & 13.0 & N/A \\
\hline 20 & 56.8 & 5 & 0.021 & 2.9 & 13.0 & $N / A$ \\
\hline 25 & 62.0 & 5 & 0.019 & 2.9 & 13.5 & N/A \\
\hline 30 & 64.1 & 5 & 0.018 & 2.9 & 13.5 & N/A \\
\hline
\end{tabular}

CONDITION (10) $9 \mathrm{ft} / \mathrm{s}$ axial velocity $(5.5 \mathrm{gpm}$ in flowmeter) $20.0 \mathrm{psig}$ transmembrane pressure

\begin{tabular}{|c|c|c|c|c|c|c|}
\hline $\begin{array}{c}\text { Time'since } \\
\text { Backpulse.(min) }\end{array}$ & $\begin{array}{l}\text { Trine } \\
\text { (sec) }\end{array}$ & $\begin{array}{l}\text { Filtrate } \\
\text { Amount.(mL) }\end{array}$ & $\begin{array}{c}\text { Fitratg Flux } \\
\text { (opmifie) }\end{array}$ & $\begin{array}{l}\text { Flowmeter } \\
\text { Reading (oipm) }\end{array}$ & $\begin{array}{l}\text { Trans Membraine } \\
\text { Pressure (psig). }\end{array}$ & $\begin{array}{c}\text { Temp. } \\
\mathrm{c}\end{array}$ \\
\hline $\begin{array}{c}0 \\
5 \\
10 \\
15 \\
20 \\
25 \\
30\end{array}$ & $\begin{array}{l}45.0 \\
64.1 \\
50.6 \\
62.6 \\
58.3 \\
60.6 \\
63.4\end{array}$ & $\begin{array}{r}15 \\
10 \\
5 \\
5 \\
5 \\
5 \\
5\end{array}$ & $\begin{array}{l}0.078 \\
0.036 \\
0.023 \\
0.019 \\
0.020 \\
0.019 \\
0.018\end{array}$ & $\begin{array}{l}5.5 \\
5.5 \\
5.1 \\
5.3 \\
5.5 \\
5.5 \\
5.5\end{array}$ & $\begin{array}{l}20.0 \\
20.0 \\
20.5 \\
21.0 \\
20.5 \\
20.0 \\
20.5\end{array}$ & $\begin{array}{l}\text { N/A } \\
\text { N/A } \\
\text { N/A } \\
\text { N/A } \\
\text { N/A } \\
\text { N/A } \\
\text { N/A }\end{array}$ \\
\hline
\end{tabular}

CONDITION (11) $6 \mathrm{ft} / \mathrm{s}$ axial velocity (3.7 gpm in flowmeter) $20.0 \mathrm{psig}$ transmembrane pressure

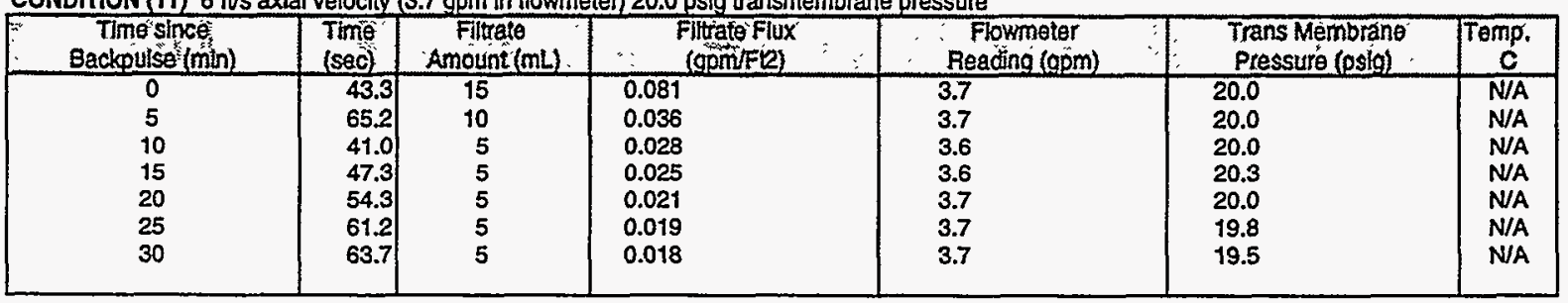

\begin{tabular}{|c|c|c|c|c|c|c|}
\hline $\begin{array}{c}\text { Time since } \\
\text { Backpulse }(\mathrm{min})\end{array}$ & $\begin{array}{l}\operatorname{Tim} \theta \\
\text { (sec) }\end{array}$ & $\begin{array}{c}\text { Filtrate } \\
\text { Amount }(\mathrm{mL})\end{array}$ & $\begin{array}{c}\text { Filfate Flux } \\
\text { (gpintela) }\end{array}$ & $\begin{array}{c}\text { Flowmioter } \\
\text { Reading (gom) }\end{array}$ & $\begin{array}{l}\text { Trans Membreno } \\
\text { Pressure (psto) }\end{array}$ & Temp. \\
\hline 0 & 23.8 & 15 & 0.147 & 3.4 & 47.0 & N/A \\
\hline 5 & 25.1 & 5 & 0.046 & 3.6 & 47.5 & N/A \\
\hline 10 & 30.0 & 5 & 0.039 & 3.6 & 47.5 & N/A \\
\hline 15 & $\mathbf{3 7 . 8}$ & 5 & 0.031 & 3.7 & 45.0 & N/A \\
\hline 20 & 41.9 & 5 & 0.028 & 3.7 & 46.0 & N/A \\
\hline 25 & 46.2 & 5 & 0.025 & 3.6 & 45.0 & N/A \\
\hline 30 & 47.4 & 5 & 0.025 & 3.7 & 46.0 & N/A \\
\hline
\end{tabular}


CONDITION (13) $6 \mathrm{ft} / \mathrm{s}$ axjal velocity $(3.7 \mathrm{gpm}$ in flowmeter) $55.0 \mathrm{psig}$ transmembrane pressure

\begin{tabular}{|c|c|c|c|c|c|c|}
\hline $\begin{array}{c}\text { Time since } \\
\text { Backpulse (min) }\end{array}$ & $\begin{array}{l}\operatorname{Tim} \theta \\
(s \theta c)\end{array}$ & $\begin{array}{c}\text { Filtrate } \\
\text { Amount }(\mathrm{mL})\end{array}$ & $\begin{array}{c}\text { Filtrate Flux } \\
\text { (gomíft2) }(0.068)\end{array}$ & $\begin{array}{c}\text { Flowmiter } \\
\text { Reading (gpm) }\end{array}$ & $\begin{array}{l}\text { Trans Membrans } \\
\text { Pressure (psig) }\end{array}$ & Temp. \\
\hline $\begin{array}{c}0 \\
5 \\
10 \\
15 \\
20 \\
25 \\
30\end{array}$ & $\begin{array}{l}17.5 \\
22.6 \\
30.4 \\
37.1 \\
36.8 \\
42.2 \\
43.2\end{array}$ & $\begin{array}{r}10 \\
5 \\
5 \\
5 \\
5 \\
5 \\
5\end{array}$ & $\begin{array}{l}0.133 \\
0.052 \\
0.038 \\
0.031 \\
0.032 \\
0.028 \\
0.027\end{array}$ & $\begin{array}{l}3.7 \\
3.6 \\
3.6 \\
3.6 \\
3.6 \\
3.7 \\
3.8\end{array}$ & $\begin{array}{l}54.0 \\
55.0 \\
56.0 \\
54.5 \\
54.5 \\
55.0 \\
55.0\end{array}$ & $\begin{array}{l}\text { N/A } \\
\text { N/A } \\
\text { N/A } \\
\text { N/A } \\
\text { N/A } \\
\text { N/A } \\
\text { N/A }\end{array}$ \\
\hline
\end{tabular}


Non-Radioactive Run 1027 Dissolved Calcine (7.94 wt \%)

CONDIION (1) $6 \mathrm{ft} / \mathrm{s}$ axial velocity ( $3.7 \mathrm{gpm}$ in flowmeter) $20.0 \mathrm{psig}$ transmembrane pressure

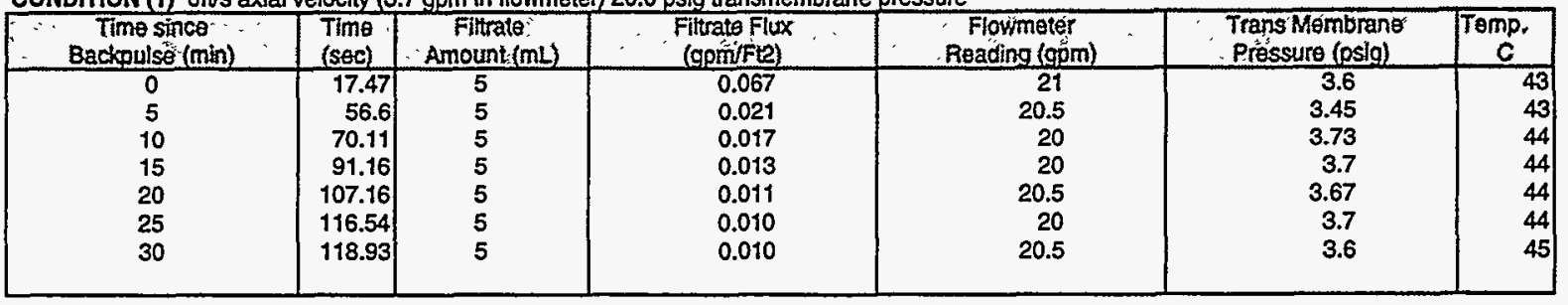

CONDITION (2) $7.5 \mathrm{ft} / \mathrm{s}$ axial velocity (4.6 gpm in flowmeter) $27.5 \mathrm{psig}$ transmembrane pressure

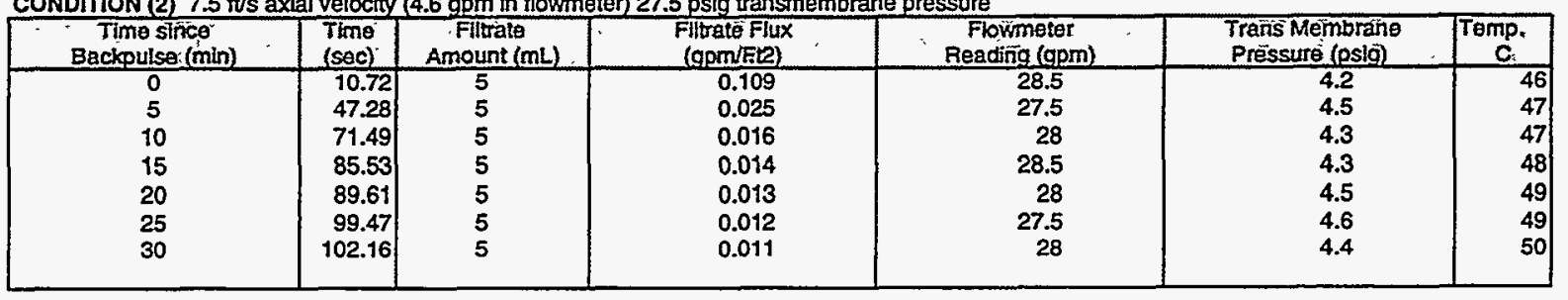

CONDITION (3) $3.0 \mathrm{ft} / \mathrm{s}$ axial velocity ( $1.8 \mathrm{gpm}$ in flowmeter) $20.0 \mathrm{psig}$ transmembrane pressure

\begin{tabular}{|c|c|c|c|c|c|c|}
\hline $\begin{array}{c}\text { Time since } \\
\text { Backoulse (min) }\end{array}$ & $\begin{array}{l}\operatorname{Tim}_{\tilde{e}} \\
(\mathrm{sec})\end{array}$ & $\begin{array}{l}\text { Fituraté } \\
\text { Amount (mL) }\end{array}$ & $\begin{array}{l}\text { Filtrate Flox } \\
\text { (opon/Ft2) }\end{array}$ & $\begin{array}{c}\text { Flowmeter } \\
\text { Reading (giom) }\end{array}$ & $\begin{array}{l}\text { Trans Membrane } \\
\text { Pressure (psig) }\end{array}$ & $\begin{array}{c}\text { Temp. } \\
\text { C }\end{array}$ \\
\hline $\begin{array}{c}0 \\
5 \\
10 \\
15 \\
20 \\
25 \\
30\end{array}$ & \begin{tabular}{r|}
12.92 \\
53.53 \\
71.85 \\
85.97 \\
111.97 \\
114.61 \\
128.79
\end{tabular} & $\begin{array}{l}5 \\
5 \\
5 \\
5 \\
5 \\
5 \\
5\end{array}$ & $\begin{array}{l}0.090 \\
0.022 \\
0.016 \\
0.014 \\
0.010 \\
0.010 \\
0.009\end{array}$ & $\begin{array}{r}19.5 \\
20 \\
19.5 \\
20 \\
20 \\
20 \\
20\end{array}$ & $\begin{array}{l}1.9 \\
1.76 \\
1.78 \\
1.77 \\
1.76 \\
1.76 \\
1.75\end{array}$ & $\begin{array}{l}48 \\
47 \\
46 \\
46 \\
45 \\
44 \\
44\end{array}$ \\
\hline
\end{tabular}

CONDITION (4) $6.0 \mathrm{ft} / \mathrm{s}$ axial velocity ( $3.7 \mathrm{gpm}$ in flowmeter) $5.0 \mathrm{psig}$ transmembrane pressure

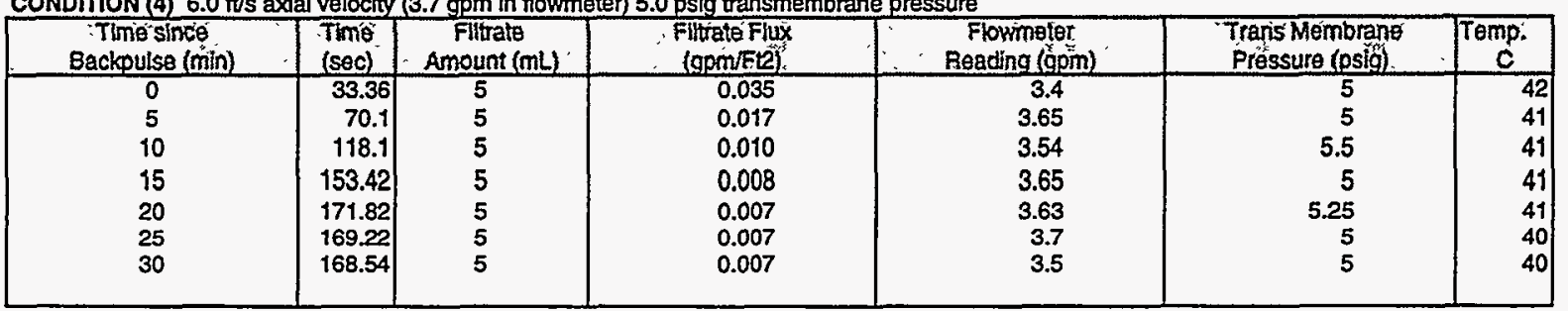

CONDITION (5) $7.5 \mathrm{ft} / \mathrm{s}$ axial velocity (4.6 gpm in flowmeter) $12.5 \mathrm{psig}$ transmembrane pressure

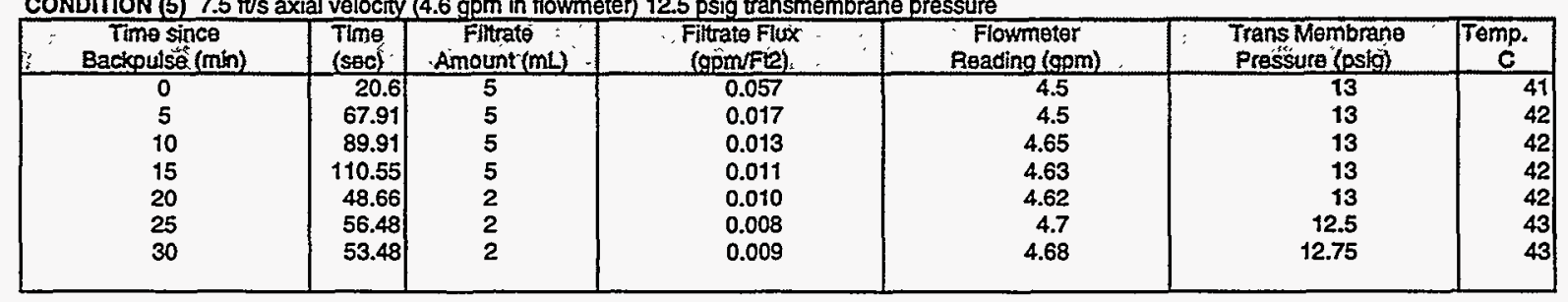

\begin{tabular}{|c|c|c|c|c|c|c|}
\hline $\begin{array}{l}\text { Time since } \\
\text { Eackpulse (n̂̀n) }\end{array}$ & $\begin{array}{l}\text { Timo } \\
(\mathrm{sec})\end{array}$ & $\begin{array}{c}\text { Fituato } \\
\text { Amount (mL) }\end{array}$ & $\begin{array}{l}\text { Filtrato Flux } \\
\text { (gopin/Ft2) }\end{array}$ & $\begin{array}{l}\text { Flowmetor } \\
\text { Reading (ópm) }\end{array}$ & $\begin{array}{l}\text { Trans Membrano } \\
\text { Préssuré (ṕsio) }\end{array}$ & $\begin{array}{c}\text { Temp. } \\
\mathrm{C}\end{array}$ \\
\hline $\begin{array}{c}0 \\
5 \\
10 \\
15 \\
20 \\
25 \\
30\end{array}$ & \begin{tabular}{r|}
13.7 \\
54.04 \\
75.81 \\
54.97 \\
66.57 \\
72.47 \\
51.75
\end{tabular} & $\begin{array}{l}5 \\
5 \\
5 \\
3 \\
3 \\
3 \\
2\end{array}$ & $\begin{array}{l}0.085 \\
0.022 \\
0.015 \\
0.013 \\
0.011 \\
0.010 \\
0.009\end{array}$ & $\begin{array}{l}3.30 \\
3.72 \\
3.60 \\
3.63 \\
3.85 \\
3.85 \\
3.80\end{array}$ & $\begin{array}{r}21 \\
20 \\
20.5 \\
20.25 \\
19.5 \\
19.75 \\
19.5\end{array}$ & $\begin{array}{l}43 \\
44 \\
43 \\
43 \\
44 \\
44 \\
44\end{array}$ \\
\hline
\end{tabular}


CONDITION (7) $4.5 \mathrm{ft}$ s axial velocity (2.8 gpm in flowmeter) $27.5 \mathrm{psig}$ transmembrane pressure

\begin{tabular}{|c|c|c|c|c|c|c|}
\hline $\begin{array}{c}\text { Thme since } \\
\text { Backpulse'(min) }\end{array}$ & $\begin{array}{l}\operatorname{Time} \\
(\sec )\end{array}$ & $\begin{array}{c}\text { Fillrate } \\
\text { Amounit (mL) }\end{array}$ & $\begin{array}{l}\text { Filfrate Flux } \\
\text { (gón/Fte) }\end{array}$ & $\begin{array}{c}\text { Flowmêter } \\
\text { Reading (gpm) }\end{array}$ & $\begin{array}{l}\text { Trans Membrane } \\
\text { Eressure (osio) }\end{array}$ & $\begin{array}{c}\text { Tèmp. } \\
\mathrm{C}\end{array}$ \\
\hline $\begin{array}{c}0 \\
5 \\
10 \\
15 \\
20 \\
25 \\
30\end{array}$ & \begin{tabular}{r|}
9.85 \\
50.41 \\
69.38 \\
47.36 \\
35.73 \\
43.73 \\
45.54
\end{tabular} & $\begin{array}{l}5 \\
5 \\
5 \\
3 \\
2 \\
2 \\
2\end{array}$ & $\begin{array}{l}0.118 \\
0.023 \\
0.017 \\
0.015 \\
0.013 \\
0.011 \\
0.010\end{array}$ & $\begin{array}{r}2.8 \\
2.6 \\
2.56 \\
2.77 \\
2.6 \\
2.82 \\
2.7\end{array}$ & $\begin{array}{r}27.5 \\
28.5 \\
29 \\
27.5 \\
28 \\
27.5 \\
28\end{array}$ & $\begin{array}{l}44 \\
44 \\
45 \\
45 \\
45 \\
45 \\
45\end{array}$ \\
\hline
\end{tabular}

CONDITON (8) $6 \mathrm{ft} / \mathrm{s}$ axial velocity ( $3.7 \mathrm{gpm}$ in flowmeter) $35 \mathrm{psig}$ transmembrane pressure

\begin{tabular}{|c|c|c|c|c|c|c|}
\hline $\begin{array}{c}\text { Time since } \\
\text { Backpulse.(min) }\end{array}$ & $\begin{array}{l}\text { Time } \\
(\mathrm{sec})\end{array}$ & $\begin{array}{l}\text { Filtrate } \\
\text { Amount }(\mathrm{mL})\end{array}$ & $\begin{array}{l}\text { Filtrate Flux } \\
\text { (gpm/Ft) }\end{array}$ & $\begin{array}{c}\text { Flowmeter } \\
\text { Reading (gom) }\end{array}$ & $\begin{array}{l}\text { Trans Membrano } \\
\text { Pressure (psig) }\end{array}$ & Temp. \\
\hline $\begin{array}{c}0 \\
5 \\
10 \\
15 \\
20 \\
25 \\
30\end{array}$ & \begin{tabular}{r|}
2.75 \\
46.43 \\
61.72 \\
45.74 \\
30.05 \\
39.85 \\
46.91
\end{tabular} & $\begin{array}{l}5 \\
5 \\
5 \\
3 \\
2 \\
2 \\
2\end{array}$ & $\begin{array}{l}0.424 \\
0.025 \\
0.019 \\
0.015 \\
0.016 \\
0.012 \\
0.010\end{array}$ & $\begin{array}{r}3.6 \\
3.55 \\
3.7 \\
3.8 \\
3.89 \\
3.65 \\
3.65\end{array}$ & $\begin{array}{r}36 \\
\quad 36 \\
35 \\
34 \\
34 \\
35 \\
35\end{array}$ & $\begin{array}{l}47 \\
47 \\
48 \\
49 \\
49 \\
50 \\
50\end{array}$ \\
\hline
\end{tabular}

CONDITION (9) $4.5 \mathrm{ft} / \mathrm{s}$ axial velocity $(2.8 \mathrm{gpm}$ in flowmeter) $12.5 \mathrm{psig}$ transmembrane pressure

\begin{tabular}{|c|c|c|c|c|c|c|}
\hline $\begin{array}{c}\text { Time since } \\
\text { Beckpulse (min) }\end{array}$ & $\begin{array}{l}\operatorname{Tine} \\
(\operatorname{sen} c)\end{array}$ & $\begin{array}{c}\text { Filtuate } \\
\text { Amount }(\mathrm{mL})\end{array}$ & $\begin{array}{l}\text { Filuate Flux } \\
\text { (gom/Ft) }\end{array}$ & $\begin{array}{c}\text { Flowmeter } \\
\text { Reading (gpm) }\end{array}$ & $\begin{array}{l}\text { Trans Membrano } \\
\text { Pressure (psig) }\end{array}$ & $\begin{array}{c}\text { Temp. } \\
\text { c. }\end{array}$ \\
\hline $\begin{array}{c}0 \\
5 \\
10 \\
15 \\
20 \\
25 \\
30\end{array}$ & \begin{tabular}{r|}
15.69 \\
55.54 \\
56.3 \\
64.04 \\
46.67 \\
67.41 \\
59.41
\end{tabular} & $\begin{array}{l}5 \\
4 \\
3 \\
3 \\
2 \\
2 \\
2\end{array}$ & $\begin{array}{l}0.074 \\
0.017 \\
0.012 \\
0.011 \\
0.010 \\
0.007 \\
0.008\end{array}$ & $\begin{array}{r}2.73 \\
2.65 \\
2.58 \\
2.75 \\
2.6 \\
2.75 \\
2.73\end{array}$ & $\begin{array}{r}13 \\
13 \\
13 \\
12.5 \\
13 \\
12.5 \\
12.75\end{array}$ & $\begin{array}{l}43 \\
43 \\
43 \\
43 \\
42 \\
42 \\
42\end{array}$ \\
\hline
\end{tabular}

CONDITON (10) $9 \mathrm{ft} / \mathrm{s}$ axial velocity (5.5 gpm in flowmeter) $20.0 \mathrm{psig}$ transmembrane pressure

\begin{tabular}{|c|c|c|c|c|c|c|}
\hline $\begin{array}{c}\text { Time since } \\
\text { Backpulse (min) }\end{array}$ & $\begin{array}{l}\operatorname{Tim} \theta \\
(\mathrm{s} \theta \mathrm{c})\end{array}$ & $\begin{array}{l}\text { Filtrate } \\
\text { Amoủnt (mL) }\end{array}$ & $\begin{array}{l}\text { Filtrate Flux } \\
\text { (gom/fin) }\end{array}$ & $\begin{array}{l}\text { Flowmeter } \\
\text { Reading }(\mathrm{gpm})\end{array}$ & $\begin{array}{l}\text { Trans Membrano } \\
\text { Pressure (psig) }\end{array}$ & $\begin{array}{c}\text { Temp. } \\
\mathrm{C}\end{array}$ \\
\hline $\begin{array}{c}0 \\
5 \\
10 \\
15 \\
20 \\
25 \\
30\end{array}$ & $\begin{array}{l}21.41 \\
59.54 \\
62.47 \\
37.54 \\
43.66 \\
41.79 \\
39.11\end{array}$ & $\begin{array}{l}5 \\
5 \\
4 \\
2 \\
2 \\
2 \\
2\end{array}$ & $\begin{array}{l}0.054 \\
0.020 \\
0.015 \\
0.012 \\
0.011 \\
0.011 \\
0.012\end{array}$ & $\begin{array}{r}5.7 \\
5.6 \\
5.55 \\
5.5 \\
5.5 \\
5.75 \\
5.7\end{array}$ & $\begin{array}{r}19.5 \\
20 \\
20.5 \\
20.5 \\
20.5 \\
t 9.5 \\
20\end{array}$ & \begin{tabular}{|l|}
43 \\
44 \\
45 \\
45 \\
46 \\
46 \\
47
\end{tabular} \\
\hline
\end{tabular}

CONDITION (11) $6 \mathrm{ft} / \mathrm{s}$ axial velocity (3.7 gpm in flowmeter) $20.0 \mathrm{psig}$ transmembrane pressure

\begin{tabular}{|c|c|c|c|c|c|c|}
\hline $\begin{array}{c}\text { Time since } \\
\text { Backpulse (min) }\end{array}$ & $\begin{array}{l}\text { Time, } \\
\text { (sec) }\end{array}$ & $\begin{array}{c}\text { Filtrate } \\
\text { Amount (mL) }\end{array}$ & $\begin{array}{l}\text { Filtrate Flux } \\
\text { (gopin/F(2) }\end{array}$ & $\begin{array}{c}\text { Flowmoler } \\
\text { Reading (ấm) }\end{array}$ & $\begin{array}{l}\text { Trans Membrane } \\
\text { Pressute (psig) }\end{array}$ & $\begin{array}{c}\text { Temp. } \\
c\end{array}$ \\
\hline $\begin{array}{c}0 \\
5 \\
10 \\
15 \\
20 \\
25 \\
30\end{array}$ & $\begin{array}{l}16.97 \\
66.78 \\
44.87 \\
38.07 \\
42.41 \\
48.85 \\
53.79\end{array}$ & $\begin{array}{l}5 \\
5 \\
3 \\
2 \\
2 \\
2 \\
2\end{array}$ & $\begin{array}{l}0.059 \\
0.017 \\
0.016 \\
0.012 \\
0.011 \\
0.010 \\
0.009\end{array}$ & $\begin{array}{r}2.3 \\
3.65 \\
3.55 \\
3.8 \\
3.65 \\
3.8 \\
3.89\end{array}$ & $\begin{array}{r}25 \\
20 \\
21 \\
20 \\
21 \\
20.5 \\
20\end{array}$ & $\begin{array}{l}46 \\
46 \\
46 \\
46 \\
46 \\
46 \\
46\end{array}$ \\
\hline
\end{tabular}

CONDITION (12) $6 \mathrm{ft} / \mathrm{s}$ axial velocity $(3.7 \mathrm{gpm}$ in flowmeter) $45.0 \mathrm{psig}$ transmembrane pressure

\begin{tabular}{|c|c|c|c|c|c|c|}
\hline $\begin{array}{c}\text { Time since } \\
\text { Backpulse (min) }\end{array}$ & $\begin{array}{l}\text { Time } \\
\text { (sec) }\end{array}$ & $\begin{array}{c}\text { Filtrate } \\
\text { Amouint }(\mathrm{mL})\end{array}$ & $\begin{array}{l}\text { Filtrate Fiux } \\
\text { fopm/Ft }^{2} \text { (g) }\end{array}$ & $\begin{array}{l}\text { Flowmeter } \\
\text { Reading (gom) }\end{array}$ & $\begin{array}{l}\text { Trans Membrano } \\
\text { Pressure (psik) }\end{array}$ & $\begin{array}{c}\text { Temp. } \\
\mathrm{c}\end{array}$ \\
\hline $\begin{array}{c}0 \\
5 \\
10 \\
15 \\
20 \\
25 \\
30\end{array}$ & $\begin{array}{l}11.35 \\
40.05 \\
51.29 \\
61.29 \\
42.41 \\
46.61 \\
53.79\end{array}$ & $\begin{array}{l}5 \\
5 \\
5 \\
5 \\
3 \\
3 \\
3\end{array}$ & $\begin{array}{l}0.103 \\
0.029 \\
0.023 \\
0.019 \\
0.016 \\
0.015 \\
0.013\end{array}$ & $\begin{array}{r}3.75 \\
3.3 \\
3.45 \\
3.6 \\
3.55 \\
3.6 \\
3.8\end{array}$ & $\begin{array}{r}44 \\
46 \\
45.5 \\
45 \\
45 \\
45 \\
44\end{array}$ & \begin{tabular}{|l|}
49 \\
51 \\
52 \\
53 \\
54 \\
55 \\
56
\end{tabular} \\
\hline
\end{tabular}




\begin{tabular}{|c|c|c|c|c|c|c|}
\hline $\begin{array}{c}\text { Time since } \\
\text { Backpulse.(min) }\end{array}$ & $\begin{array}{l}\text { Time } \\
(\sec )\end{array}$ & $\begin{array}{c}\text { Filfrate } \\
\text { Amount } m \text { L }\end{array}$ & $\begin{array}{c}\text { Filtiate Flux } \\
\text { (oom/Fe) }(0.068)\end{array}$ & $\begin{array}{c}\text { Fowmoter } \\
\text { Reading (oo m) }\end{array}$ & $\begin{array}{l}\text { Trans Membrano } \\
\text { Pressure (pstä) }\end{array}$ & Temp. \\
\hline $\begin{array}{c}0 \\
5 \\
10 \\
15 \\
20 \\
25 \\
30\end{array}$ & $\begin{array}{r}8.37 \\
30.98 \\
26.05 \\
42.41 \\
35.6 \\
39.55 \\
28.1\end{array}$ & $\begin{array}{l}5 \\
5 \\
3 \\
4 \\
3 \\
2 \\
2\end{array}$ & $\begin{array}{l}0.139 \\
0.038 \\
0.027 \\
0.022 \\
0.020 \\
0.012 \\
0.017\end{array}$ & $\begin{array}{r}4.1 \\
3.6 \\
3.8 \\
3.8 \\
3.3 \\
3.65 \\
3.8\end{array}$ & $\begin{array}{r}55 \\
55.5 \\
54.5 \\
55.8 \\
56 \\
55 \\
47.5\end{array}$ & $\begin{array}{l}60 \\
62 \\
64 \\
65 \\
67 \\
68 \\
69\end{array}$ \\
\hline
\end{tabular}




\begin{tabular}{|c|c|c|c|c|c|c|}
\hline \multicolumn{7}{|l|}{ BASELINE WATER RUN \#1 } \\
\hline \multirow{2}{*}{ Condition } & \multirow{2}{*}{$\begin{array}{c}\text { Flowmeter } \\
\text { Reading (gpm) }\end{array}$} & \multirow{2}{*}{$\begin{array}{l}\text { Transmembrane } \\
\text { Pressure (psig) }\end{array}$} & \multicolumn{2}{|c|}{ Filtrate Flowrate } & \multirow[t]{2}{*}{$\mathrm{mL} / \mathrm{Sec}$} & \multirow{2}{*}{$\begin{array}{c}\text { Temp } \\
\text { C }\end{array}$} \\
\hline & & & $\mathrm{mL}$ & $\mathrm{Sec}$ & & \\
\hline $\begin{array}{c}\text { (4) - } 6 \mathrm{ft} / \mathrm{s} \text { axial velocity: } \\
\text { (3.7 gpm in flowmeter) } \\
5 \mathrm{psig} \text { TMP }\end{array}$ & 3.62 & 5 & 50 & 25 & 2.00 & 34 \\
\hline $\begin{array}{l}\text { (9) }-4.5 \mathrm{ft} / \mathrm{s} \text { axial velocity: } \\
(2.8 \mathrm{gpm} \text { in flowmeter) } \\
12.5 \mathrm{psig} \text { TMP }\end{array}$ & 2.86 & 12.6 & 50 & 10.52 & 4.75 & 35 \\
\hline $\begin{array}{c}\text { (5) - } 7.5 \mathrm{ft} / \mathrm{s} \text { axial velocity: } \\
\text { (4.6 gpm in flowmeter) } \\
12.5 \mathrm{psig} \text { TMP }\end{array}$ & 4.55 & 12.6 & 50 & 11.05 & 4.52 & 36 \\
\hline $\begin{array}{c}\text { (1,6,11) - } 6 \mathrm{ft} / \mathrm{s} \text { axial velocity: } \\
\text { (3.7 gpm in flowmeter) } \\
20 \text { psig TMP }\end{array}$ & 3.69 & 20 & 50 & 7 & 7.14 & 37 \\
\hline $\begin{array}{c}\text { (3) - } 3 \mathrm{ft} / \mathrm{s} \text { axial velocity: } \\
\text { (1.8 gpm in flowmeter) } \\
20 \mathrm{psig} \text { TMP }\end{array}$ & 1.75 & 20 & 50 & 7.03 & 7.11 & 38 \\
\hline $\begin{array}{l}\text { (10) - } 9 \mathrm{ft} / \mathrm{s} \text { axial velocity: } \\
\text { (5.5 gpm in flowmeter) } \\
20 \text { psig TMP }\end{array}$ & 5.6 & 20 & 50 & 6.61 & 7.56 & 40 \\
\hline $\begin{array}{c}\text { (7) - } 4.5 \mathrm{ft} / \mathrm{s} \text { axial velocity: } \\
(2.8 \mathrm{gpm} \text { in flowmeter) } \\
27.5 \mathrm{psig} \text { TMP }\end{array}$ & 2.79 & 27.5 & 50 & 4.78 & 10.46 & 42 \\
\hline $\begin{array}{c}\text { (2) - } 7.5 \mathrm{ft} / \mathrm{s} \text { axial velocity: } \\
\text { (4.6 gpm in flowmeter) } \\
27.5 \text { psig TMP }\end{array}$ & 4.57 & 27.5 & 50 & 4.67 & 10.71 & 46 \\
\hline $\begin{array}{l}\text { (8) - } 6 \mathrm{ft} / \mathrm{s} \text { axial velocity: } \\
\text { (3.7 gpm in flowmeter) } \\
35 \text { psig TMP }\end{array}$ & 3.6 & 35 & 50 & 3.61 & 13.85 & 50 \\
\hline
\end{tabular}




\begin{tabular}{|c|c|c|c|c|c|c|}
\hline \multicolumn{7}{|c|}{ BASELINE WATER RUN \#2 } \\
\hline \multirow[t]{2}{*}{ Condition } & \multirow{2}{*}{$\begin{array}{c}\text { Flowmeter } \\
\text { Reading (gpm) }\end{array}$} & \multirow{2}{*}{$\begin{array}{l}\text { Transmembrane } \\
\text { Pressure (psig) }\end{array}$} & \multicolumn{2}{|c|}{ Filtrate Flowrate } & \multirow[t]{2}{*}{$\mathrm{mL} / \mathrm{Sec}$} & \multirow{2}{*}{$\begin{array}{c}\text { Temp } \\
\mathrm{C}\end{array}$} \\
\hline & & & $\mathrm{mL}$ & Sec & & \\
\hline $\begin{array}{c}\text { (4) }-6 \mathrm{ft} / \mathrm{s} \text { axial velocity: } \\
\text { (3.7 gpm in flowmeter) } \\
5 \text { psig TMP }\end{array}$ & 3.75 & 5 & 30 & 95.62 & 0.31 & 30 \\
\hline $\begin{array}{c}\text { (9) - } 4.5 \mathrm{ft} / \mathrm{s} \text { axial velocity: } \\
\text { (2.8 gpm in flowmeter) } \\
12.5 \text { psig TMP }\end{array}$ & 2.84 & 12.5 & 30 & 41.15 & 0.73 & 31 \\
\hline $\begin{array}{c}\text { (5) }-7.5 \mathrm{ft} / \mathrm{s} \text { axial velocity: } \\
\text { (4.6 gpm in flowmeter) } \\
12.5 \mathrm{psig} \text { TMP }\end{array}$ & 4.6 & 12.7 & 30 & 40.06 & 0.75 & 32 \\
\hline $\begin{array}{c}(1,6,11)-6 \mathrm{ft} / \mathrm{s} \text { axial velocity: } \\
(3.7 \mathrm{gpm} \text { in flowmeter }) \\
20 \mathrm{psig} \text { TMP }\end{array}$ & 3.72 & 20 & 30 & 26.52 & 1.13 & 32 \\
\hline $\begin{array}{c}\text { (3) - } 3 \mathrm{ft} / \mathrm{s} \text { axial velocity: } \\
\text { (1.8 gpm in flowmeter) } \\
20 \mathrm{psig} \text { TMP }\end{array}$ & 1.8 & 21.5 & 30 & 23.5 & 1.28 & 33 \\
\hline $\begin{array}{c}\text { (10) - } 9 \mathrm{ft} / \mathrm{s} \text { axial velocity: } \\
(5.5 \mathrm{gpm} \text { in flowmeter) } \\
20 \mathrm{psig} \text { TMP }\end{array}$ & 5.45 & 20 & 30 & 26.25 & 1.14 & 33 \\
\hline $\begin{array}{c}\text { (7) - } 4.5 \mathrm{ft} / \mathrm{s} \text { axial velocity: } \\
(2.8 \mathrm{gpm} \text { in flowmeter) } \\
27.5 \mathrm{psig} \text { TMP }\end{array}$ & 2.75 & 27.5 & 30 & 19.13 & 1.57 & 34 \\
\hline $\begin{array}{l}\text { (2) - 7.5 ft/s axial velocity: } \\
\text { (4.6 gpm in flowmeter) } \\
27.5 \mathrm{psig} \text { TMP }\end{array}$ & 4.58 & 27.75 & 30 & 18.4 & 1.63 & 35 \\
\hline $\begin{array}{c}\text { (8) - } 6 \mathrm{ft} / \mathrm{s} \text { axial velocity: } \\
\text { (3.7 gpm in flowmeter) } \\
35 \mathrm{psig} \text { TMP }\end{array}$ & 3.7 & 35 & 30 & 14.86 & 2.02 & 36 \\
\hline
\end{tabular}




\begin{tabular}{|c|c|c|c|c|c|c|}
\hline \multicolumn{7}{|c|}{ BASELINE WATER RUN \#3 } \\
\hline \multirow[t]{2}{*}{ Condition } & \multirow{2}{*}{$\begin{array}{c}\text { Flowmeter } \\
\text { Reading (gpm) }\end{array}$} & \multirow{2}{*}{$\begin{array}{l}\text { Transmembrane } \\
\text { Pressure (psig) }\end{array}$} & \multicolumn{2}{|c|}{ Filtrate Flowrate } & \multirow[t]{2}{*}{$\mathrm{mL} / \mathrm{Sec}$} & \multirow{2}{*}{$\begin{array}{c}\text { Temp } \\
\text { C }\end{array}$} \\
\hline & & & $\mathrm{mL}$ & $\mathrm{Sec}$ & & \\
\hline $\begin{array}{c}\text { (4) }-6 \mathrm{ft} / \mathrm{s} \text { axial velocity: } \\
\text { (3.7 gpm in flowmeter) } \\
5 \mathrm{psig} \text { TMP }\end{array}$ & 3.75 & 5 & 30 & 95.62 & 0.31 & 30 \\
\hline $\begin{array}{c}\text { (9) - } 4.5 \mathrm{ft} / \mathrm{s} \text { axial velocity: } \\
(2.8 \mathrm{gpm} \text { in flowmeter) } \\
12.5 \mathrm{psig} \text { TMP }\end{array}$ & 2.84 & 12.6 & 30 & 41.15 & 0.73 & 31 \\
\hline $\begin{array}{c}\text { (5) - } 7.5 \mathrm{ft} / \mathrm{s} \text { axial velocity: } \\
\text { (4.6 gpm in flowmeter) } \\
12.5 \mathrm{psig} \text { TMP }\end{array}$ & 4.6 & 12.7 & 30 & 40.06 & 0.75 & 32 \\
\hline $\begin{array}{c}(1,6,11)-6 \mathrm{ft} / \mathrm{s} \text { axial velocity } \\
(3.7 \mathrm{gpm} \text { in flowmeter) } \\
20 \mathrm{psig} \text { TMP }\end{array}$ & 3.72 & 20 & 30 & 26.52 & 1.13 & 32 \\
\hline $\begin{array}{c}\text { (3) - } 3 \mathrm{ft} / \mathrm{s} \text { axial velocity: } \\
\text { (1.8 gpm in flowmeter) } \\
20 \mathrm{psig} \text { TMP }\end{array}$ & 1.8 & 21.5 & 30 & 23.5 & 1.28 & 33 \\
\hline $\begin{array}{c}\text { (10) - } 9 \mathrm{ft} / \mathrm{s} \text { axial velocity: } \\
\text { (5.5 gpm in flowmeter) } \\
20 \mathrm{psig} \text { TMP }\end{array}$ & 5.48 & 20 & 30 & 26.25 & 1.14 & 33 \\
\hline $\begin{array}{c}\text { (7) - } 4.5 \mathrm{ft} / \mathrm{s} \text { axial velocity: } \\
(2.8 \mathrm{gpm} \text { in flowmeter) } \\
27.5 \mathrm{psig} \text { TMP }\end{array}$ & 2.75 & 27.5 & 30 & 19.13 & 1.57 & 34 \\
\hline $\begin{array}{c}(2)-7.5 \mathrm{ft} / \mathrm{s} \text { axial velocity: } \\
\text { (4.6 gpm in flowmeter) } \\
27.5 \mathrm{psig} \text { TMP }\end{array}$ & 4.58 & 27.75 & 30 & 18.4 & 1.63 & 35 \\
\hline $\begin{array}{c}\text { (8) - } 6 \mathrm{ft} / \mathrm{s} \text { axial velocity: } \\
\text { (3.7 gpm in flowmeter) } \\
35 \mathrm{psig} \text { TMP }\end{array}$ & 3.7 & 35 & 30 & 14.86 & 2.02 & 36 \\
\hline
\end{tabular}




\begin{tabular}{|c|c|c|c|c|c|c|}
\hline \multicolumn{7}{|c|}{ BASELINE WATER RUN \#4 } \\
\hline \multirow[t]{2}{*}{ Condition } & \multirow{2}{*}{$\begin{array}{c}\text { Flowmeter } \\
\text { Reading (gpm) }\end{array}$} & \multirow{2}{*}{$\begin{array}{l}\text { Transmembrane } \\
\text { Pressure (psig) }\end{array}$} & \multicolumn{2}{|c|}{ Filtrate Flowrate } & \multirow[t]{2}{*}{$\mathrm{mL} / \mathrm{Sec}$} & \multirow{2}{*}{$\begin{array}{c}\text { Temp } \\
\text { C }\end{array}$} \\
\hline & & & $\mathrm{mL}$ & Sec & & \\
\hline $\begin{array}{c}\text { (4) }-6 \mathrm{ft} / \mathrm{s} \text { axial velocity: } \\
\text { (3.7 gpm in flowmeter) } \\
5 \mathrm{psig} \text { TMP }\end{array}$ & 3.7 & 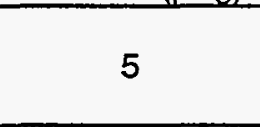 & 10 & 22.56 & 0.44 & 37 \\
\hline $\begin{array}{c}\text { (9) }-4.5 \mathrm{ft} / \mathrm{s} \text { axial velocity: } \\
(2.8 \mathrm{gpm} \text { in flowmeter) } \\
12.5 \mathrm{psig} \text { TMP }\end{array}$ & 2.4 & 13.5 & 10 & 16.6 & 0.60 & 38 \\
\hline $\begin{array}{c}\text { (5) }-7.5 \mathrm{ft} / \mathrm{s} \text { axial velocity: } \\
\text { (4.6 gpm in flowmeter) } \\
12.5 \mathrm{psig} \text { TMP }\end{array}$ & 4.7 & 12.5 & 10 & 13.2 & 0.76 & 38 \\
\hline $\begin{array}{c}1,6,11) \text { - } 6 \mathrm{ft} / \mathrm{s} \text { axial velocity } \\
\text { (3.7 gpm in flowmeter) } \\
20 \text { psig TMP } \\
\end{array}$ & 3.7 & 20 & 10 & 9.97 & 1.00 & 39 \\
\hline $\begin{array}{c}\text { (3) - } 3 \mathrm{ft} / \mathrm{s} \text { axial velocity: } \\
\text { (1.8 gpm in flowmeter) } \\
20 \mathrm{psig} \text { TMP }\end{array}$ & 1.6 & 21 & 10 & 9.16 & 1.09 & 39 \\
\hline $\begin{array}{c}\text { (10) - } 9 \mathrm{ft} / \mathrm{s} \text { axial velocity: } \\
\text { (5.5 gpm in flowmeter) } \\
20 \text { psig TMP }\end{array}$ & 5.2 & 21 & 10 & 6.06 & 1.65 & 40 \\
\hline $\begin{array}{c}\text { (7) }-4.5 \mathrm{ft} / \mathrm{s} \text { axial velocity: } \\
(2.8 \mathrm{gpm} \text { in flowmeter) } \\
27.5 \mathrm{psig} \text { TMP } \\
\end{array}$ & 2.8 & 27.5 & 10 & 7.06 & 1.42 & 41 \\
\hline $\begin{array}{c}\text { (2) }-7.5 \mathrm{ft} / \mathrm{s} \text { axial velocity: } \\
\text { (4.6 gpm in flowmeter) } \\
27.5 \mathrm{psig} \text { TMP }\end{array}$ & 4.5 & 27.5 & 10 & 5.92 & 1.69 & 43 \\
\hline $\begin{array}{c}\text { (8) - } 6 \mathrm{ft} / \mathrm{s} \text { axial velocity: } \\
\text { (3.7 gpm in flowmeter) } \\
35 \text { psig TMP }\end{array}$ & 3.5 & 35.5 & 10 & 6.53 & 1.53 & 45 \\
\hline
\end{tabular}

